\title{
1 SUBDUCTION EROSION AND ARC VOLCANISM
}

2 Susanne M. Straub ${ }^{1^{\dagger}}$ Arturo Gómez-Tuena², Paola Vannucchi3i,4

$3{ }^{1}$ Lamont Doherty Earth Observatory at the Columbia University, 61 Route 9W, Palisades NY

4 10964, U.S.A.

$5 \quad$ 2Centro de Geociencias, Universidad Nacional Autónoma de México, Querétaro 76230, Mexico

6 3Earth Sciences Department, Royal Holloway, University of London, Egham TW20 0EX, UK

$7 \quad$ 'Dipartimento di Scienze della Terra, Universita' degli Studi di Firenze, 50121, Firenze, Italy

$8 \quad{ }^{\dagger}$ e-mail: smstraub@ldeo.columbia.edu

\section{ABSTRACT}

10 Tectonic or subduction erosion refers to the removal of upper plate material from the 11 forearc at convergent margins. Subduction erosion has been suggested to represent a

12 major process associated with the transfer of crustal material into the Earth's mantle at 13 subduction zones ${ }^{1-4}$. However, few studies have attempted to trace the fate of eroded

14 forearc crust beneath volcanic arcs, where the eroded crust might first emerge after

15 mixing with the upper mantle, owing to the formidable challenge associated with

16 quantifying the rate of subduction erosion and the contribution of eroded crust to arc

17 magmas. In this Review, we summarize the evidence for subduction erosion at

18 convergent margins and show that, through integration of geochemical and geological

19 data in arc settings where critical crustal lithologies can be accessed, quantification of the

20 contribution of eroded forearc crust to arc magmas is possible ${ }^{5-8}$. We further emphasize

21 the importance of establishing arc-forearc compositional links, and illustrate the role of

22 arc petrogenetic models for determining whether the eroded forearc crust contributes

23 substantially (that is, greater than a few percent) to the construction of new arc crust in

24 subduction zones ${ }^{5,9}$, or whether it is primarily exported to the deeper mantle.

\section{5 [H1] INTRODUCTION}


26 Plate tectonics results in the transfer of crustal material into the Earth's convecting

27 mantle at subduction zones ${ }^{1,10-13}$. Subducted crust can include marine sediment, which

28 forms through deposition of eroded material from the upper continental crust on the

29 subducting lithospheric plate ${ }^{14}$; altered oceanic crust (AOC); and tectonically eroded

30 crust ('subduction erosion [G]') removed from the crustal basement of the overriding

31 plate ${ }^{1,3,4,15,16}$. Trench sediment and AOC have measurable volumes and distinct

32 compositions, which allow their distribution in the mantle to be traced through the

33 composition of $\operatorname{arc}^{10,11,17-20}$ and intraplate magmas $13,21,22$. However, despite the clear

34 potential for eroded material to influence $\operatorname{arc}^{3,5,6,8,23}$ and intraplate magmatism $13,24,25$, as

35 well as the Phanerozoic balance of crustal destruction and growth ${ }^{3,26}$, the role of the

36 eroded crust in magma petrogenesis remains uncertain.

37 Subduction erosion removes crustal material from the forearc [G] of the upper plate

38 along modern subduction zones. Although subduction erosion operates at depths that

39 are largely inaccessible ${ }^{2}$, it can be indirectly inferred from geological data of the forearc

40 (Fig. 1). For example, the large-scale and long-term subsidence of the forearc (up to 5,000

41 meters) $)^{1,26,27}$, alongside bathymetric and seismic images consistent with a dynamic, time-

42 progressive erosion of the forearc ${ }^{2,4,28,29}$, indicates that subduction erosion can transfer

43 similar quantities of crust to the mantle as subduction of trench sediment $t^{3,16,23}$.

44 After mixing with the mantle, subducted crustal material first emerges at volcanic arcs

45 located above the descending slab ${ }^{30-32}$. Comparative trench-arc studies demonstrate that,

46 following transfer of crustal components to relatively shallow mantle depths ( 100-200

$47 \mathrm{~km}$ ), the geochemical signatures of trench sediments ${ }^{10,11,14}, \mathrm{AOC}^{31,33-37}$, and lithospheric

48 serpentinites ${ }^{38-40}$ re-emerge in arc magmas. However, few studies have addressed

49 whether eroded crust is recycled in the mantle wedge and, therefore, contributes to arc

50 magmas $^{5,6,8,13,23}$. Detecting the presence of eroded crust in arc magmas is challenging as it

51 blends with the other recycled crustal components, particularly trench sediment ${ }^{3,23}$. In

52 addition, contribution from eroded crust can also present similar geochemical signatures

53 to those produced by interaction of primary arc magmas [G] with pre-existing crustal 
54 basement en route to the $\operatorname{surface}^{41}$ (Fig. 1).

55 In this Review, we present a summary of subduction erosion processes at convergent

56 margins and discuss how erosion recycling in arcs can be identified through detailed

57 arc-forearc analysis. In addition, we note that recent analyses of erosion recycling

58 beneath several volcanic arcs worldwide, alongside new models of arc petrogenesis,

59 indicate that subduction erosion can have an important role in the geochemical

60 modification of both the shallow and deep mantle.

\section{1 [H1] THE SUBDUCTION PATHWAY OF ERODED CRUST}

62 Convergent margins are typically classified as either 'erosive' or 'accretionary', based

63 on the balance between the removal of crustal material by subduction erosion and 64 growth of the upper plate owing to 'frontal accretion [G] '42-45 or 'underplating [G] '46

65 (Fig. 2, Supplementary Information) ${ }^{1,16}$. At erosive margins, there is a net removal of

66 material from the upper plate ${ }^{46,47}$, whereas at accretionary margins there is net growth.

67 However, it is important to note that subduction erosion can still occur beneath

68 accretionary margins, and thus contribute to the geochemical signature of arc volcanoes

69 worldwide.

70 A common feature of actively eroding margins is the 'frontal prism [G] ' (Fig. 1[a]), 71 which has a semi-constant width of $\sim 10$ to $20 \mathrm{~km}$, variable thickness $(<1 \mathrm{~km}$ to $\sim 5-6 \mathrm{~km})$

72 and is commonly characterized by landward-dipping seismic reflectors. Frontal prisms

73 are typically composed of upper plate material (that is, sediment and disaggregated

74 basement), which accumulates at the toe (Fig. 1[b]) of the outer forearc ${ }^{2}$, or sediment

75 scraped off the incoming plate to form a small accretionary prism [G] ${ }^{48}$. The frontal

76 prism is backed by a resistive 'backstop [G]' (Fig. 1[c]), which represents the

77 dynamically stronger rock framework of the forearc.

78 As the incoming oceanic plate subducts beneath the overriding plate, basal erosion [G]

79 of the forearc occurs. Erosion of the forearc causes the trenchward migration of the

80 strong material of the backstop, which is then gradually weakened until it becomes part 
81 of the frontal prism. As the process continues, material that was once part of the strong

82 backstop is eventually eroded $\mathrm{away}^{2}$. On the mid to upper continental slope (Fig. 1[d])

83 high-angle, landward-dipping normal faults (Fig. 1[e]) with small to moderate 50-

$84300 \mathrm{~m}$ displacements can herald the impending fracturing of the rock framework ${ }^{2,28}$.

85 The frontal prism can reduce the plate boundary friction by 'loading' (that is,

86 overpressuring) fluid-rich sediments. Dewatering and upward fluid migration results in

87 weakening of the upper plate and upward migration of the plate boundary shear zone ${ }^{2}$.

88 The consequent incorporation of upper plate material to the top of the subduction

89 channel [G] (Fig. 1[f]) causes 'basal erosion'. In addition, fluid percolation assists

90 fracturing at the base of the upper plate, beneath the middle continental slope, and thus

91 incorporation of this upper plate material into the subduction channel (Fig. 1[g]). The

92 thinner the incoming sediments, the higher the plate boundary friction and, therefore,

93 the fracturing of the upper plate 2 . The physical damage to the forearc is at a maximum

94 when seamounts, oceanic plateaus and ridges on the lower plate collide with the

95 forearc ${ }^{4,28}$. Material entering the subduction channel is likely to be accommodated by

96 grabens and half-grabens (Fig. 1[h]) that dissect the lower plate.

97 If the eroded crust escapes immediate re-accretion (that is, underplating) beneath the

98 forearc, it will be transported into the mantle alongside the downgoing plate. Fluids

99 released from the lower plate are absorbed by the forearc mantle wedge, forming

100 serpentinite. As mantle wedge temperatures rise with increasing distance from trench,

101 release of fluids from the slab (Fig. 1[i]) and/or resulting serpentinites could trigger

102 melting at slab depths $>80-100 \mathrm{~km}$ (ref. ${ }^{49,50}$ ). With increasing slab depth, the efficiency of

103 material transfer from the slab to the wedge increases owing to the buoyant rise of 'slab

104 diapirs [G] ' (Fig. 1[k]) 51-53 or, if the slab solidus is intersected beneath the arc front, slab

105 partial melts [G] ${ }^{54}$.

106 Diapirs rising from the subducting slab transfer large volumes of low-density crustal

107 material, such as eroded crust or sediment, into the core of the mantle wedge ${ }^{51}$.

108 Additionally, mélanges diapirs (Fig. 1[1]), which rise from intensely sheared and mixed, 
high-pressure mélange zones between the eclogitic slab and overlying mantle peridotite, can integrate transport the bulk of the AOC, instead of only low-mass AOC fluids, into

111 the core of the mantle wedge ${ }^{34,52,55,56}$. As the rising slab material mixes with the hot core

112 of the mantle wedge it will begin to melt (alongside the surrounding mantle peridotite)

113 and subsequently erupt as arc magmas after ascent through the crustal basement (Fig.

$1141[\mathrm{~m}])$. The residual slab material is then exported to the deeper mantle (Fig. 1[n]).

\section{5 [H1] DISCOVERING SUBDUCTION EROSION}

116 Subduction erosion cannot be directly observed or quantified. Instead, the process of

117 subduction erosion, and the rate of crustal destruction, can be inferred from a

118 combination of geological and geophysical forearc observations 1,15,16,23,57-59.

119 Characteristic features of upper plate destruction, such as forearc thinning or

120 truncation, can also be caused by extension or the presence of strike-slip faults parallel to

121 the trench. However, where subduction erosion is inferred (Fig. 2 and Supplementary

122 Information) it is the only process that can account for the entirety of the observations,

123 which implies net loss of forearc material. In addition, subduction erosion provides a

124 framework for quantifying forearc crustal loss.

125 [H2] Destruction of the upper plate crust.

126 Early evidence for the importance of subduction erosion comes from the large-scale 127 loss of forearc crust at convergent margins $\mathrm{s}^{60-64}$. For example, the $200 \mathrm{~km}$ landward 128 migration of the active central and southern Andean volcanic arc ( 15-46 $\mathrm{S})$, evidenced

129 by the eastward younging remnants of older arcs located between the coast and the 130 Holocene $\operatorname{arc}^{60}$, indicates that there has been time-progressive destruction of the Andean 131 forearc crust since the Early Jurassic ${ }^{1,60}$. At different arc systems worldwide, evidence for 132 forearc loss includes the missing portions of accretionary prisms (for example, in 133 Nankai) ${ }^{65}$, unaccountable forearc subsidence in Japan ${ }^{66}$ and Costa Rica ${ }^{26,27}$, truncation of 134 the crystalline roots of older magmatic belts near the shoreline and offshore (as in the 135 Mexican Pacific coast) 67,68 , or the testimony of detrital zircon chronology that records the 
136 existence of now-vanished Paleozoic and Mesozoic batholiths of the proto-Japan arc ${ }^{69}$.

137 Major strike-slip faults have also been suggested to cause largescale forearc loss.

138 However, along trench transport of the forearc by trench-parallel strike-slip faults would

139 generate doubled-up forearcs in addition to forearc loss, which are not observed.

140 Instead, in the late 1970s, ocean drilling revealed the presence of forearc subsidence ${ }^{66,70 .}$

141 For example, drilling $\sim 90 \mathrm{~km}$ from the trench axis offshore Japan, in water $1560 \mathrm{~m}$ deep,

142 penetrated an erosional angular unconformity $1200 \mathrm{~m}$ below sea floor, which could be

143 seismically traced regionally to $\sim 10 \mathrm{~km}$ from the trench axis. The sediments above the

144 unconformity are $48 \mathrm{~m}$ thick, unconsolidated, non-marine Oligocene, which were

145 interpreted as nearshore/beach deposits ${ }^{66}$. Thus, since the Oligocene, broad, regional

146 outer forearc subsidence of nearly $2800 \mathrm{~m}$, at a rate of $\sim 140 \mathrm{~m} / \mathrm{my}$ (ref. ${ }^{66}$ ), must have

147 occurred to accommodate the burial of these sub-aerial sediments beneath the overlying

148 marine slope sediments ${ }^{1}$.

149 In a simple model of an accretionary prism, subsidence of the outer forearc is

150 unexpected as plate convergence and under-thrusting should result in isostatic uplift of

151 the prism's outer slope, owing to thickening of lower density crustal material71,72.

152 However, forearc subsidence can also result from changes in slab dip ${ }^{73-76}$, crustal

153 thinning by forearc extension or basal erosion. Although normal, extensional faults are

154 found in erosive margins ${ }^{2}$, their displacement and resulting crustal thinning cannot

155 account for the measured forearc subsidence 27,66 . For example, there are no major

156 extensional structures large enough to explain the $\sim 3000 \mathrm{~m}$ of subsidence in the Japan

157 outer forearc ${ }^{66,77,78}$. In addition, models that consider the subsidence of the outer Japan

158 forearc to be driven by variations in plate kinematics, associated with the post-Oligocene

159 opening of the Japan Sea ${ }^{79,80}$, assume that there has been a constant forearc volume since

160 the Oligocene. Yet, the Oligocene outer forearc volume, inferred from the upper plate

161 cross-sectional area between the trench and the drilled Oligocene coastline, only

162 accounts for about $25 \%$ of the modern outer forearc volume, inconsistent with constant-

163 volume models. 
164 Subsequent work has documented large-scale and long-lived subsidence in other 165 forearcs ${ }^{1,16}$, such as Costa Rica, where multi-beam bathymetry provided spectacular 166 images of the visual damage to the forearc by the head-on collision of incoming high167 relief seamounts. Seamounts plow through the frontal prism and leave grooved, 168 elongate depressions in the forearc slope up to $\sim 55 \mathrm{~km}$ landward $2,28,81$, indicating that 169 seamount subduction is able to effectively remove fragmented upper plate material' 2.

170 To the south, subduction of the aseismic Cocos Ridge, a $\sim 18 \mathrm{~km}$ thick and $\sim 200 \mathrm{~km}$ 171 wide basaltic ridge ${ }^{82}$ that rises $\sim 2000 \mathrm{~m}$ high above the surrounding seafloor (Fig. 2), is 172 associated with the landward retreat of the Middle America Trench ${ }^{83,84}$. Ocean drilling 173 indicates $\sim 1 \mathrm{~km}$ of uplift of the forearc continental shelf within only $\sim 0.3 \mathrm{My}$, starting at $174 \sim 2 \pm 0.2 \mathrm{Ma}$, which was followed by equally fast subsidence of $\sim 1.5 \mathrm{~km}$ (refs. ${ }^{4,83,85}$ ). The 175 rapid vertical motion of the forearc, and retreat of the trench, suggests that the onset of 176 Cocos Ridge subduction caused accelerating compression, followed by outer forearc 177 removal and thinning by basal erosion ${ }^{4,86}$.

178 An alternative hypothesis states that the arrival of the Cocos Ridge at the trench would 179 cause horizontal shortening and thickening of the forearc, without mass loss, and thus 180 trench retreat. In this model, the subduction of a much smaller seamount is required to 181 explain the initial, rapid vertical forearc movements ${ }^{84,87}$. However, contemporaneous 182 thickening and subsidence of the outer forearc is required ${ }^{84,87}$, inconsistent with the 183 isostatic uplift predicted following subduction of an $\sim 18 \mathrm{~km}$ thick basaltic ridge.

184 As a result, time-progressive forearc destruction by basal erosion ${ }^{1,4}$ represents the only 185 process that can explain the observed subsidence of forearcs worldwide, and the 186 volumes of crustal forearc that are lost. In addition, subduction erosion is consistent 187 with, several forearc features that have been revealed by seismic images, such as the 188 existence of frontal prisms in Costa Rica and Guatemala (Fig. 1)², high-angle normal 189 faulting patterns on the continental slope of Costa Rica, Nicaragua and South America ${ }^{28}$, 190 mega-lenses of upper plate material embedded in the subduction channel in Costa 191 Rica ${ }^{28,88}$ and upper plate imbricate landward-dipping forearc thrusts that are truncated 
192 by plate boundary shear zones in the Japan Trench ${ }^{77}$. Additionally, high-temperature

$193\left(\sim 85-150^{\circ} \mathrm{C}\right)$ vents located along forearc normal faults document the upward fluid

194 drainage from the lower plate that causes the subsurface hydrofracturing [G] of the rock

195 framework ${ }^{89}$.

196 Although the volume of forearc data available for the Central American margin is

197 rarely seen elsewhere ${ }^{4}$ (see Supplementary Information), sufficient observations exists to

198 demonstrate that erosive destruction of the upper plate is a common consequence of

199 plate convergence ${ }^{15}$. In contrast, the hydrated, less brittle lower plate largely escapes

200 physical destruction except for the loss of the incoming sediment that is accreted to the

201 forearc ( $70 \%$ on average; see Supplementary Information).

\section{2 [H2] Eroded crustal volumes.}

203 The influence of subduction erosion on the solid rock geochemical cycle is controlled

204 by the rate of forearc erosion, or forearc volume lost, within a given timespan. Erosion

205 rates are estimated through reconstruction of the volume lost using data on the forearc

206 crustal thickness, the extent and duration of forearc subsidence, and the rate of

207 landward trench migration ${ }^{15,16,27}$ (Supplementary Information).

208 As the capacity of the subduction channel to consume eroded material is a function of

209 several parameters, including the topography of the incoming plate, the convergence

210 rate and the hydrogeology of the forearc and plate boundary ${ }^{90-92}$, erosion rates can be

211 difficult to constrain in the highly dynamic forearc environment. For example, the

212 subduction channel might widen at depth, and thus allow more eroded material to enter

213 the plate boundary shear zone, or shrink, causing underplating down to at least $\sim 30-40$

$214 \mathrm{~km}$ depth (as imaged by reflection and refraction seismic profiles and inferred from tell-

215 tale forearc uplifts) $)^{93-95}$. As a result, a single margin might display along-strike changes

216 from an erosive to an accretionary and underplating regime ${ }^{4,96,97}$. Similarly, a margin

217 with a large, long-lived accretionary prism can turn erosive, removing the accreted

218 material by frontal erosion [G] ${ }^{95}$. 
219 The classification of a given margin as erosive or accretionary typically represents a 220 time-integrated, long-term average (Fig. 2) ${ }^{3,15}$. As forearc data improve, the rates of 221 forearc erosion are constantly revised. The most up-to-date estimates of the rates of 222 forearc erosion and sediment subduction, calibrated on Pliocene-Pleistocene ( $\leq 5 \mathrm{Ma})$ 223 geophysical and geological forearc data and the tectonic background of the modern 224 subduction zones, are presented in the Supplementary Information. Critically, the new 225 rates are the first that have been adjusted for sediment loss by underplating and forearc 226 accretion and confirm that most margins (>60\%) are erosive (consistent with earlier 227 compilations) $)^{1,15,16}$.

228 Erosive and accretionary margins can also have distinctive forearc characteristics ${ }^{15}$. 229 Accretionary margins are characterized by lower (orthogonal) convergence rates ( $\sim 36 \pm 22$ $230 \mathrm{~km} / \mathrm{my}$ ) and higher sediment fluxes (trench fill $>1 \mathrm{~km}$ thick). They are commonly found 231 near continents and large river mouths that have had a high terrigenous sediment flux 232 through the Cenozoic ${ }^{14,15}$ and, in particular, since the onset of the Northern hemisphere 233 glaciation at $\sim 2.6 \mathrm{Ma}$ (ref. ${ }^{1}$ ). Frontal prisms constructed from accreted sediments tend to 234 have shallow forearc slopes $<3^{\circ}$ and taper angles $<10^{\circ}$ (the angle between the subducting 235 slab surface and forearc slope). In contrast, erosive margins have higher convergence 236 rates $(\sim 71 \pm 23 \mathrm{~km} / \mathrm{my})$ and thin $(<1 \mathrm{~km})$ trench fills. Their forearcs are built of stronger 237 lithified sediments, magmatic and crystalline rocks with steeper slopes $\left(>3^{\circ}\right.$ and $\left.8^{\circ}\right)$ and 238 bigger taper angles $\left(>7^{\circ} \text { up to } 20^{\circ}\right)^{4,15}$.

239 The dominance of erosive margins implies a global net loss of forearc, especially since 240 mass balances points toward forearc loss even at accretionary margins ${ }^{66,96,98}$. However, 241 the volumes of eroded crust at accretionary margins are difficult to estimate 57,97 and, as a 242 result, global averages of erosion rates are currently based on estimates from erosive 243 margins ${ }^{1,3}$. Despite the inherent uncertainties and data gaps, some important features 244 emerge. First, the most recent estimates of the average global erosion rates $(\sim 66 \pm 34$ $245 \mathrm{~km} 3 /$ per $\mathrm{km}$ of trench length $/ \mathrm{my}\left(\mathrm{km}^{3} / \mathrm{km} / \mathrm{my}\right)$; Supplementary Information) are higher 246 than the early estimates of $\sim 26 \mathrm{~km}^{3} / \mathrm{km} / \mathrm{my}_{\text {(ref. }}{ }^{1}$ ), owing to the improved quality and 
quantity of forearc data. Second, once the influence of crustal underplating is taken into account, the estimated rate of sediment subduction decreases from the early estimates of $\sim 23 \mathrm{~km}^{3} / \mathrm{km} / \mathrm{my}$ (ref. ${ }^{1}$ ), or $\sim 41-45 \mathrm{~km}^{3} / \mathrm{km} / \mathrm{my}$ if $100 \%$ sediment subduction at erosive

250 margins is assumed, to $\sim 14 \pm 8 \mathrm{~km}^{3} / \mathrm{km} / \mathrm{my}$. Third, all estimates agree that tectonically

251 eroded crust contributes at least half and likely up to $\sim 80 \%$ of the total crust lost to

252 mantle through trench sediment and subduction erosion $(\sim 77 \text { to } 81 \mathrm{~km} 3 / \mathrm{km} / \mathrm{my})^{1,3,15,16}$.

253 Fourth, the combined rate of crust loss via sediment subduction and forearc erosion is

254 similar to the estimated global arc crust production rate [G] by melting of the mantle,

255 which is usually estimated to be $\sim 30$ to $150 \mathrm{~km}^{3} / \mathrm{km} / \mathrm{my}$ (refs. ${ }^{1,3,15,16}$ ). As a result,

256 tectonically eroded crust should influence arc volcanism ${ }^{5}$, mantle evolution ${ }^{13}$, and also

257 models of continental crust destruction and growth ${ }^{3,99}$.

\section{8 [H1] CONNECTING SUBDUCTION EROSION AND ARCS}

259 Arc magmas have radiogenic isotope ratios (that is, ${ }^{87} \mathrm{Sr} /{ }^{86} \mathrm{Sr},{ }^{206} \mathrm{~Pb} /{ }^{204} \mathrm{~Pb},{ }^{206} \mathrm{~Pb} /{ }^{204} \mathrm{~Pb}$, $260{ }^{206} \mathrm{~Pb} /{ }^{204} \mathrm{~Pb},{ }^{143} \mathrm{Nd} /{ }^{144} \mathrm{Nd}$ and ${ }^{176} \mathrm{Hf} /{ }^{177} \mathrm{Hf}$ ) that are intermediate between those of the 261 depleted upper mantle and the enriched continental crust ${ }^{11,32}$. For example, the $262{ }^{143} \mathrm{Nd} /{ }^{144} \mathrm{Nd}$ ratios of arc magmas (expressed as $\varepsilon \mathrm{Nd}[\mathrm{G}]$ ) are lower than that of the 263 depleted upper mantle $(\varepsilon N d \sim 10)$, but typically higher than that of continental crust $264(\varepsilon \mathrm{Nd}<0)^{13,100,101}$. A simple first-order assumption is that eroded crust resembles 265 continental crust in major elements, trace elements and radiogenic isotope $\operatorname{ratios}^{1,3,23}$. As 266 a result, it has been suggested that the $\varepsilon N d$ of primary arc magmas [G] should scale to 267 the total amount of continental crust (trench sediment + eroded crust) recycled beneath 268 each $\operatorname{arc}^{3}$. The proportion of eroded crust involved in the petrogenesis of arc magmas 269 can then be determined through the ratio of eroded crust to subducted trench sediment 270 calculated from forearc observations ${ }^{3}$. As tectonically eroded crust contributes 271 substantially to the total subducted crust ( $75 \%$ on average, Supplementary 272 Information), low- $\varepsilon \mathrm{Nd}$ arcs should contain the largest contribution of recycled eroded 273 crust.

274 A global map of arc $\varepsilon N d$ (Fig. 2), however, does not support such a simple 
275 compositional link between the rate of subduction erosion and arc magma compositions.

276 Although volcanoes of the Central (CVZ, 15-28 ${ }^{\circ}$ ) and Southern (SVZ, 33-46 ${ }^{\circ}$ )

277 Volcanic Zones have low average $\varepsilon \mathrm{Nd}$ signatures of -5 and +4 , respectively, consistent

278 with the long-term erosional history of the $\operatorname{margin}^{1}, \varepsilon \mathrm{Nd}$ is high in other erosional

279 margins ( $>+5)$. For example, $\varepsilon N d$ values up to +7 and +9 are observed in the Costa Rica

280 and Tonga arcs where subduction of the Cocos and Louisville Ridges, respectively,

281 increase forearc erosion ${ }^{1,4}$. In fact, in both locations, arc $\varepsilon \mathrm{Nd}$ values reach a maxima at

282 the intersection of ridge and forearc, which points to the erosion recycling of the high-

$283 \varepsilon N d$ crustal forearc basement.

284 The often-made assumption that subduction erosion only recycles continental crust is 285 an oversimplification. Instead, as expected from the location of active subduction zones,

286 forearc erosion may abrade any material that builds forearc basement, which can include

287 upper continental crust, depleted or enriched oceanic crust, accreted sediments,

288 allochthonous terranes, or the poorly characterised lower continental crust. In an end-

289 member scenario, erosion recycling of various crustal materials could produce the global

290 distribution of $\varepsilon \mathrm{Nd}$ in arc magmas. In addition, erosion recycling likely contributes to

291 the highly heterogeneous nature of the mantle by recycling materials other than

292 continental crust ${ }^{102}$, oceanic lithophere ${ }^{103}$ and $\mathrm{AOC}^{104}$.

293 There are, however, other factors that can influence the $\varepsilon N d$ of global arc magmas. For 294 example, crustal assimilation can systematically lower the $\varepsilon \mathrm{Nd}$ of arcs constructed on 295 ancient continental basement relative to the $\varepsilon \mathrm{Nd}$ of oceanic $\operatorname{arcs}^{41,105}$. Arc $\varepsilon N d$ might also 296 be influenced by variations in the mantle wedge composition, which appears to be more 297 depleted beneath oceanic arcs ${ }^{106}$ than continental arcs ${ }^{107-109}$. Chemical variety can also be 298 introduced by variations in the amount and composition of trench sediment $t^{11,19,33,110,111}$.

299 To distinguish between the different possibilities, comprehensive major element, trace

300 element and isotope studies from the trench, fore-arc, arc basement, and arc magmas are 301 needed in individual arc settings. Modeling of such datasets, supported by experimental 302 data, can determine whether forearc recycling controls arc magma composition, or is 
subordinate to the other processes.

\section{[H1] CASE STUDIES IN VOLCANIC ARCS}

305 It is a formidable challenge to distinguish and quantify the contribution of an eroded crustal component, of unknown composition, to arc magmas, especially owing to the influence of other co-mingled source components. The debate surrounding the contribution of eroded forearc crust to arc magma petrogenesis in several arc systems worldwide illustrate the challenge.

[H2] The Central and Southern Andean arc.

311 There is strong geological evidence for subduction erosion along the Andean margin 312 between Peru and South Chile ( 10-46 ${ }^{\circ}$ S), for example, large-scale crustal loss, forearc 313 subsidence $^{1}$ and characteristic fault patterns ${ }^{112}$, have led several studies to consider the 314 influence of recycled eroded forearc on Andean arc magmas $8,23,113$. For example, an early 315 study indicated that the increase in the ${ }^{87} \mathrm{Sr} /{ }^{86} \mathrm{Sr}$ of Holocene Andean arc magmas north 316 of $\sim 34^{\circ} \mathrm{S}$ was causally related to a contextual increase of ongoing subduction erosion ${ }^{114}$.

317 However, subsequent studies of the Andean arc's Cenozoic evolution inferred that 318 erosion recycling was not continuous, but episodic ${ }^{8,115-117}$.

319 In the Andean CVZ and SVZ, the compositional evolution of the arc between the 320 Oligocene ( $25 \mathrm{Ma}$ ) and present day can be reconstructed from the remnants of the older 321 arcs. The older arcs are exposed between the coast and the Holocene arc in trench322 parallel, eastward younging volcanic belts that were left behind as the Andean volcanic 323 front retreated to the east ${ }^{60}$. The exposed compositional evolution of the Andean arc 324 allow the identification of two Neogene periods ( 19-16 Ma and $\sim 8-3 \mathrm{Ma}$ ) that are 325 characterized by the presence of small-volume, primitive arc magmas that have up to $326700 \mathrm{ppm} \mathrm{Cr}, 300 \mathrm{ppm} \mathrm{Ni}$, and $10 \mathrm{wt} \% \mathrm{MgO}$ (refs. ${ }^{8,115,116}$ ), as well as steep rare earth 327 element (REE) patterns and high $\mathrm{Sr} / \mathrm{Y}, \mathrm{Sr} / \mathrm{Yb}$ and $\mathrm{Sm} / \mathrm{Yb}$ ratios that are characteristic of 328 'adakitic' magmas. The lower $\varepsilon N d$ and higher ${ }^{87} \mathrm{Sr} /{ }^{86} \mathrm{Sr}$ of the adakitic magmas, 329 compared to their preceding magmas, points to an origin from an enriched mantle 
331 The two Neogene pulses coincide with periods of heightened eastward arc retreat, a 332 change from an extensional to a compressional basement regime, crustal thickening, and 333 a decrease in the volcanic productivity of the eastwards migrating volcanic arc ${ }^{8,115,118}$. At

334 a constant subduction geometry, accelerated arc retreat points to enhanced tectonic 335 forearc erosion, which can cause mantle wedge enrichment through the incorporation of 336 the subducted eroded crust ${ }^{8,115,116}$. In addition, similar chemo-temporal correlations were 337 observed in the Central Aleutian arc, where adakitic magmas preferentially erupt during 338 peaks of forearc erosion and arc retreat ( 7-5 Ma) or in the waning stages of short-term 339 enhanced magmatic activity $(\sim 37-29 ; \sim 16-11 \text { and } \sim 7-5 \mathrm{Ma})^{119,120}$.

340 The combination of adakitic signatures, crustal thickening and tectonic evolution has 341 also been hypothesized to be driven by crustal thickening, rather than enhanced 342 subduction erosion. Crustal thickening stalls the underlying mantle flow field, which in 343 turn forces the arc front to migrate away from the trench ${ }^{121}$, and causes an increase in 344 trace element ratios such as $\mathrm{La} / \mathrm{Yb}$. However, although there is strong evidence for 345 fluctuations between extensional and compressional upper plate regimes in the Andean 346 SVZ since the Miocene ${ }^{122}$, tectonically driven crustal thickening cannot account for the 347 large scale loss of forearc crust along the Andean margin, the presence of older arc 348 products at the coast and forearc subsidence ${ }^{112}$.

349 Intriguingly, in the Andean subduction erosion model presented above, compositional 350 links between the forearc and arc are only visible in rare, periodic, small-volume mafic 351 magmas ${ }^{8,115}$, which implies that most of the eroded material must be returned to the 352 mantle 8,115 . However, the question of whether strong arc-forearc compositional links are 353 present, outside of the two Neogene periods of adakitic magmatism, remains debated.

354 A recent study of the northern SVZ ( 34-35 $\mathrm{S})$ used $\mathrm{Sr}-\mathrm{Nd}-\mathrm{Pb}$ isotopes and 355 incompatible trace element ratios to suggest that primitive, high-Mg\# [G] arc magmas 356 are sourced from a mantle that contains an enriched low-eNd, upper crustal 357 component ${ }^{113}$. Isotope mixing systematics rule out a substantial contribution from low- 
$\varepsilon N d$ trench sediment and instead point to a low- $\varepsilon N d$ upper continental crust component that was recycled by forearc erosion ${ }^{113,123}$. However, the role of subduction erosion on controlling the composition of Andean arc magmas was recently challenged by a study that approximated the composition of the SVZ and CVZ Andean eroded forearc crust though a compilation of published data from the outcropping igneous and metamorphic Andean basement ${ }^{124}$. No basement composition found in the compilation was able to

364 recreate the $\mathrm{Sr}, \mathrm{Ba}, \mathrm{Eu} / \mathrm{Eu}^{*}$ and ${ }^{87} \mathrm{Sr} /{ }^{86} \mathrm{Sr}$ systematics of mafic rocks from Maipo and Don

365 Casimiro in the SVZ $\left(\sim 34.16^{\circ} S\right)^{124}$, a volcanic system that had previously been connected

366 with erosion recycling ${ }^{113}$. Similar ambiguity is also present in two CVZ volcanoes

367 near $28^{\circ} \mathrm{S}, \sim 700 \mathrm{~km}$ farther to the north, which show consistency with erosion recycling

368 in Sr-Nd isotope space, but a clear signal of crustal contamination in their Pb-isotope 369 compositions $^{116}$.

370 The crustal proxies used in studies of the CVZ 116,125 and SVZ ${ }^{8,41}$ represent the accessible upper Phanerozoic Andean crust. However, the deep Andean basement between

372 Colombia and Patagonia is composed of various Grenvillian-age (1-1.5 Ga) crustal terranes $^{126}$. Assimilation of the inaccessible deep crustal basement ${ }^{41,127}$ by either crustal

374 contamination or tectonic erosion of the deeper Andean forearc basement ${ }^{8,115}$ is

375 imaginable, but difficult to test in face of the rare inliers of Grenvillian-age crust.

376 Further complexity is introduced into the petrogenesis of the Andean arc magmas by 377 the possible presence of an enriched mantle, low- $\varepsilon \mathrm{Nd}$ component in the mantle wedge. 378 The enriched mantle component is hypothesized to be either low- $\varepsilon \mathrm{Nd}$ subcontinental 379 lithospheric mantle ${ }^{109}$ or components derived from it ${ }^{107}$. In such a scenario, the low $\varepsilon N d$ 380 of the mafic CVZ and SVZ magmas is not related to subduction erosion ${ }^{125}$, but originates 381 from a heterogeneous mantle that is transported by corner flow [G] ${ }^{128}$ from behind the 382 arc to the arc front (where it is overprinted by low-mass slab fluids [G] ) ${ }^{107,124,129-131}$. Thus, 383 to fully understand the influence of subduction erosion on Andean magmatism through 384 time, the challenge remains to find means of quantitatively distinguishing between 385 contributions from mantle, deep crustal basement and forearc to the composition of arc 
front magmas.

387

388

390

391

392

393

394

395

396

397

398

399

400

402

403

\section{[H2] The Central American Volcanic Arc (CAVA).}

$$
\text { The CAVA (Fig. 2) is a well-studied, long-term Neogene erosive system }{ }^{132} \text {. Multiple }
$$
ocean drilling expeditions on the forearc reveal that the forearc erosion rate increased from $\sim 12$ to $80 \mathrm{~km}^{3} / \mathrm{km} / \mathrm{my}$ between $\sim 6$ and $\sim 2.5 \mathrm{Ma}$, and then to $\sim 140-153 \mathrm{~km} 3 / \mathrm{km} / \mathrm{my}$ in the Pleistocene. In addition, a regional Pleistocene maximum forearc erosion rate of $\sim 1125 \mathrm{~km}^{3} / \mathrm{km} / \mathrm{my}$ (ref. ${ }^{132}$ ) is observed at the intersection of the forearc with the aseismic Cocos Ridge, which arrived at the trench at $\sim 2.5 \mathrm{Ma}$ and represents oceanic crust that has been thickened from $\sim 6$ to $\sim 18 \mathrm{~km}$ (ref. ${ }^{82}$ ) by Galapagos hotspot magmatism ${ }^{83,133}$.

$$
\text { Concurrent with increasing forearc erosion between } \sim 6 \text { and 1.5 Ma, the CAVA magmas }
$$
in central Costa Rica and western Panama transitioned from normal calc-alkaline arc magmas to enriched, 'OIB-type' magmas that resemble, in some trace element and isotope ratios, the intraplate magmas of the Galapagos hotspot ${ }^{133-135}$. The temporal change in the magmatic compositions of the CAVA could be related to the onset of recycling of the Cocos Ridge at $\sim 2.5 \mathrm{Ma}\left(\right.$ ref. $\left.^{83}\right)$. However, the contribution of eroded forearc crust to the CAVA magmas remains unclear.

It has been suggested that subduction erosion could transfer the OIB-type $\mathrm{Pb}$ isotope signatures to the arc from a forearc, that is constructed of accreted OIB-type Cretaceous ophiolites and fragments of the Caribbean Large Igneous Province ${ }^{135}$. However, several other models have been proposed to explain the OIB-type $\mathrm{Pb}$ isotope signature of the CAVA magmas, including advection of enriched mantle by trench-parallel flow beneath the CAVA ${ }^{136}$; a slab window allowing Galapagos asthenosphere to flow into the mantle wedge $^{137}$; a mantle wedge infested with Galapagos plume components ${ }^{138}$, and a mantle wedge metasomatized by slab components from subducted Galapagos-type oceanic crust $^{134,139}$. Thus, the Pleistocene - Holocene CAVA provides an example of a forearc-arc setting where eroded forearc might be recycled, but the influence of the recycled eroded crust on arc magma petrogenesis cannot be determined owing to the compositional 
413 diversity of the source components that might be present.

\section{4 [H2] The Transmexican Volcanic Belt (TMVB).}

415 The TMVB allows the influence of erosion recycled to be directly tested as it has an 416 accessible and distinct trench and forearc input ${ }^{5-7}$, and a well-investigated arc output ${ }^{140}$.

417 In addition, the composition of the ambient mantle [G] wedge can be approximated 418 through contemporaneous rear-arc magmas that erupt directly behind the volcanic 419 front $^{141,142}$.

420 The crystalline roots of deeply eroded, older Mesozoic-Cenozoic arcs are commonly 421 uplifted above sea level along the Pacific coast 67,68 and their sharp truncation indicates 422 that substantial tectonic removal of the Mexican forearc has occurred ${ }^{143}$. In addition, 423 along the northwest coastal segment, forearc loss by subduction erosion is strongly 424 supported by observed subsidence ${ }^{15}$, arc retreat and forearc uplift ${ }^{68,143-146}$. To the 425 southeast, truncation of the Mexican margin might have been enhanced since at least the 426 early Miocene by the left-lateral translation of a large crustal basement block ('Chortís 427 block') from southern Mexico to its present position in Central America ${ }^{147-150}$. Therefore, 428 contribution of recycled eroded crust to the composition of the Plio-Quaternary TMVB 429 arc magmas is likely.

$430 \quad$ The TMVB produces high-Mg\# basalts and andesites with up to $600 \mathrm{ppm} \mathrm{Cr}$ and 431280 ppm Ni (ref. ${ }^{140}$ ). The presence of high-Ni olivines (up to 5400 ppm Ni) with mantle432 like ${ }^{3} \mathrm{He} /{ }^{4} \mathrm{He}$ signatures $(7-8 \mathrm{Ra})^{151}$, indicate that the TMVB magmas undergo negligible 433 contamination during passage through the $\sim 30-50 \mathrm{~km}$ thick continental basement ${ }^{140,152}$. 434 Intriguingly, olivines with the mantle-like ${ }^{3} \mathrm{He} /{ }^{4} \mathrm{He}$ ratios also have high, crustal $\delta^{18} \mathrm{O}$ 435 signatures (+5.6 to $+6.6 \%$; Fig. $3 a, b)$, which points towards the contribution of slab436 derived continental crustal material to the TMVB mantle wedge ${ }^{6}$.

437 Contribution of recycled continental crust to the TMVB mantle wedge is also consistent 438 with the radiogenic isotope and trace element systematics of the TMVB arc magmas. 439 Regardless of being erupted from large-volume composite (several hundreds of $\mathrm{km}^{3}$ ) or 
440 small monogenetic centers $\left(<1 \mathrm{~km}^{3}\right)$, the TMVB magmas form tight, linear arrays in

441 radiogenic isotope space that are bracketed by forearc and/or trench lithologies and the

442 composition of the TMVB mantle wedge $\mathrm{e}^{6,7,153}$. In addition, the isotopic arrays of the

443 TMVB magmas cut through the much broader spectrum of isotopic compositions

444 measured in the TMVB continental basement, which varies widely in thickness,

445 composition and age $\mathrm{e}^{140,154-156}$.

446 Critically, the Nd-Hf isotope and trace element systematics of the TMVB arc magmas

447 exclude the trench sediment as an important endmember in magma petrogenesis ${ }^{6}$. The

448 trench sediment has a high $\mathrm{Nd} / \mathrm{Hf}$ ratio of $\sim 17$ (ref. ${ }^{157}$ ); however, the linear TMVB array

449 in $\varepsilon N d$ vs $\varepsilon H f$ [G] space requires that all slab components have a low $\mathrm{Nd} / \mathrm{Hf}$ ratio of $\sim 4$ -

450 5, similar to the mantle wedge (Fig. 3). Recycled mid-ocean ridge basalt (MORB) type

451 AOC has a low $\mathrm{Nd} / \mathrm{Hf}$ ratio ( 4-5), but has a similarly high $\varepsilon N d-\varepsilon H f$ to the mantle

452 wedge $^{6}$. Thus, the low- $\varepsilon N d-\varepsilon H f$ eroded forearc crust with a low $\mathrm{Nd} / \mathrm{Hf}$ of $\sim 5$ is the only

453 possible unradiogenic endmember of the TMVB array. If recycled in sufficient

454 quantities, the eroded crust will be able to conceal the signature of the subducted trench

455 sediment in the TMVB magmas (that is, a curved isotopic mixing trend in $\varepsilon \mathrm{Nd}$ vs $\varepsilon \mathrm{Hf}$

456 space; Fig. 3) $)^{5,6}$.

457 Comparison of alongstrike radiogenic isotope trends in the arc and forearc have

458 recently been used to further investigate the influence of erosion recycling in the TMVB,

459 testing the hypothesis that the composition of the arc volcanics should reflect the parallel

460 trend of the respective forearc lithologies ${ }^{5}$. The forearc trend was reconstructed through

461 river mouth sediments at the Pacific coast, which are lithological composites of larger,

462 but regionally limited, catchment areas ${ }^{5}$. Critically, the along-strike trends observed in

463 the forearc data are similar to the parallel trends of major andesitic volcanoes

464 (Sangangüey, Tequila, Colima), consistent with a compositional control by forearc crust

465 recycling $^{5}$ (Fig. 4).

466 Further evidence for erosion recycling in the TMVB emerges from zircons in a

467 Holocene andesite lava flow from the summit of Malinche, a major stratovolcano of the 
Eastern TMVB (Fig. 5)7. The cores of the zircons have a Paleo-Proterozoic to Miocene age distribution that are inconsistent with the Ordovician to Jurassic ages and poly-

470 deformed metamorphic lithologies of the deep crustal basement beneath Malinche ${ }^{158}$

471 (indicating that they are not assimilated during passage through the crust). However,

472 the zircon age distribution is remarkably similar to that of detrital zircons in crustal

473 sediments from the Papagayo river, which drains into the Pacific where the trajectory of

474 the slab subducting beneath Malinche intersects the trench, and from a hemipelagic mud

475 unit recovered offshore at DSDP Site $467,<100 \mathrm{~km}$ to the southeast of Papagayo's river

476 mouth (Fig. 5). As such, the Malinche zircon cores could be unmolten residues of eroded

477 forearc crust that survived burial, erosion, subduction and ascent from the slab in

478 comparatively cool silicic mélange diapirs [G] that traverse through a hot mantle wedge

$479\left(>1000^{\circ} \mathrm{C}\right)$, to eventually re-appear as rare xenocrysts in the Malinche magmas ${ }^{7}$.

480 Overall, the TMVB displays the best evidence for contribution of tectonically eroded 481 crust to arc magma petrogenesis. The apparent presence of eroded forearc crust in in all 482 major TMVB magmas series indicates that erosion recycled might widely affect global 483 arc magmas $5,6$.

\section{4 [H1] SUMMARY AND FUTURE PERSPECTIVES}

485 Subduction erosion is a common process in subduction zones and is responsible for the 486 removal of large volumes of crust from the upper plate forearc. The volumes of eroded 487 crust are so large that they must factor into the perpetual cycle of crustal destruction 488 through subduction and new crust formation from the mantle as strongly as the 489 subduction of AOC, trench sediment and hydrated mantle. In this Review, we have 490 shown that integrated trench-forearc-arc studies at convergent margins, where eroded 491 crust is formed and subducted, are crucial in determining the volume and composition 492 of eroded material. However, although case studies provide strong arguments for the 493 importance of erosion recycling, many questions still remain. Specifically, ongoing work 494 continues to highlight several areas of research that need to be targeted in future studies 495 to further explore and investigate the influence of erosion recycling at convergent 
margins.

\section{[H2] Forearc exploration.}

$$
\text { Establishing compositional connections between the arc and forearc provides key }
$$
evidence for erosion recycling in arcs. The TMVB highlights what can be achieved in a favorable setting, whereas the Andean SVZ and CVZ demonstrate the issues that can arise if critical lithologies are not available or indistinct in composition. Future studies of the compositional variations along an arc and forearc must take into account the greater compositional variability of the forearc compared to the incoming plate. As a result, more sampling sites along the forearc are required to test along-strike arc-forearc correlation. Pilot studies could be used to identify the potential of a possible study areas. In addition, drilling to the zones of active subduction erosion, which is now technically possible ${ }^{159}$, could help characterize the age, composition and origin of the eroding lithologies and thus improve constraints on the mechanism and rates of forearc erosion ${ }^{4}$.

\section{[H2] The origin of arc andesites.}

Current estimates for the proportion of recycled eroded crust contributing to arc magmas range from a few ( 2-6) percent in the Andean and Aleutian arcs, $8113,115,119,135$ to several tens ( 20-50) of percent in the TMVB5,6,160,161. A low percent contribution of eroded crust to arc magmas implies that the subducted eroded crust is mostly returned to the deep mantle ${ }^{1}$ and new arc crust is primarily extracted from mantle 107,109,162. However, a high percent contribution implies a more balanced distribution of eroded crust between the shallow arc and the deeper mantle, and indicates that new arc crust might be partially rebuilt from subducted eroded crust ${ }^{5}$.

The disparity in the numbers estimated for the contribution of eroded crust to arc magmas is dependent on the arc genetic model employed and, more specifically, on the long-standing problem of whether primary arc magmas are basaltic or silicic ${ }^{151,163-168}$. Primary arc basalts $(\mathrm{MgO} \geq 10 \mathrm{wt} \% ; \mathrm{Mg} \# \geq 72)^{169}$, and high-Mg\# andesites that form by hydrous mantle melting ${ }^{170-172}$, contain only a few percent of slab materials (eroded 
crust+AOC+trench sediment) prior to crustal differentiation. However, in primary andesitic and dacitic (that is, silicic) melts that erupt with little need for additional

525 crustal differentiation, the contribution of slab material can be much larger ${ }^{5,151,165,173,174}$.

526 Few arc magmas display the steep heavy REE patterns and high $\mathrm{Sr} / \mathrm{Y}$ and $\mathrm{Sr} / \mathrm{Yb}$ ratios

527 that are considered characteristic of melts from a garnet-bearing source, which precludes

528 global arc magmas originating from silicic partial melts of the subducting eclogitic

529 slab ${ }^{175,176}$. However, in recent years two models have been proposed that aim to explain

530 the formation of primary silicic magmas (that is, andesites to dacites) that are rich in slab

531 material but do not have a 'garnet signature'. The first model proposes that reactive

532 infiltration of silicic slab melts into the peridotite mantle wedge produces secondary,

533 silica-oversaturated pyroxenite segregations ${ }^{151}$, which then produce primary silicic melts

534 upon melting at shallower levels in the mantle wedge $\mathrm{e}^{177,178}$. Formation of mantle

535 pyroxenite consumes tens of percent of silicic slab material, and results in the presence

536 of melts that contain contributions from both slab and mantle, in which only a few

537 elements, such as $\mathrm{Mg}, \mathrm{Fe}, \mathrm{Ti}$ and the tell-tale heavy $\mathrm{REE}$, remain mantle-

538 controlled ${ }^{151,160,161,179}$. This process could create high-Mg\# andesites ${ }^{151}$ independent from

539 melt water content in all arc settings, such as the TMVB ${ }^{140}$, Kamchatka ${ }^{180-182}$, New

540 Zealand ${ }^{183-185}$, the Western Aleutians ${ }^{186}$ and the Cascades ${ }^{187-190}$

541 The second model that has been proposed builds on the idea of slab diapirs and 542 mélanges 9,51,52,191, which are predicted to buoyantly rise from a layer of silicic, low-

543 density crustal material on top of the slab, between the dense eclogitic below and mantle

544 peridotite above ${ }^{51,52}$. Silicic diapirs can either rise to the base of the crust where they

545 'relaminate' 9,191 , or erupt as arc magmas after reactive interaction and melting in the

546 mantle wedge ${ }^{5-7}$. Slab diapirs transfer a substantial mass of bulk crust to the wedge, and

547 can include elements not mobilized in slab partial melts, such as $\mathrm{Fe}, \mathrm{Mg}$, and Ti from

548 granodiorites ${ }^{6}$ or as part of 'mélange diapirs' that contain mafic material from the

$549 \mathrm{AOC}^{34,55,56}$. The compositional consequences of slab or mélange diapirs for arc magmas

550 has only recently begun to be explored ${ }^{5-7,34,52,56}$. Nevertheless, there is clear potential for 
551 the creation of an enriched, heterogeneous mantle that produces a diverse spectrum of

552 basaltic and silicic primary arc melts with flat heavy REE patterns ${ }^{5,6,173}$.

553 Importantly, a global evaluation of arc magma compositions does not support the

554 traditional model of melt silica increase by crustal contamination, providing additional

555 evidence for the presence of primary silicic magmas generated in the mantle wedge

556 (Fig. 6). An increase in the silica content of a magma by incorporation of fusible, silicic

557 upper plate crust into hot basaltic mantle melts seems intuitive, especially given the

558 strong and pervasive melt mixing features observed in all arc magmas ${ }^{105,151,192-199}$.

559 However, contrary to expectations, melt $\mathrm{SiO}_{2}$ contents do not correlate with radiogenic

560 isotope ratios, such as ${ }^{207} \mathrm{~Pb} /{ }^{204} \mathrm{~Pb}$, that are highly sensitive to assimilation of continental

561 crust (Fig 6, 7).

562 It is possible that the isotope ratios of basaltic arc magmas, especially $\mathrm{Pb}$ isotopes, are 563 fixed by small amounts of contamination in the deep crustal basement $t^{116,127,200}$. Basaltic

564 melts might then evolve to silicic melts by closed system fractional crystallization ${ }^{201}$, and

565 mix by recharge mixing [G] during polybaric, multi-stage melt ascent. Rigorous testing

566 of arc input-output relationships, using microanalysis of crystalline phases

567 (phenocrysts) $160,181,195,202-204$ and their melt inclusions ${ }^{205,206}$, is required to investigate the

568 possible assimilation of additional components in the deep crust. However, detailed

569 microbeam studies of phenocrysts in both the simple magma systems of monogenetic

570 volcanoes ${ }^{161,207}$ and the complex systems of composite volcanoes ${ }^{198,199}$ have, so far, failed

571 to reveal a co-genetic evolution from basalt to dacite. Instead, the observed melt

572 diversity, as evidenced by the range of both phenocryst and bulk-rock compositions, has

573 been attributed to the presence of multiple, basaltic to silicic, melt components in the

574 sub-volcanic plumbing system $153,161,195,199,208,209$, In some cases, the range of melt

575 compositions that are present have been interpreted to represent primary melts from a

576 heterogeneous mantle created by active subduction ${ }^{151}$. 


\section{7 [H2] Mantle wedge heterogeneity.}

578 Aside from determining the contribution of crustal assimilation, another factor that

579 influences the estimated contribution of subducted material to arc magmas is the

580 composition of the ambient mantle wedge. Traditionally, the mantle wedge has been

581 considered to represent depleted upper mantle ${ }^{210}$, which is actively enriched by

582 subduction through addition of enriched slab components, including high-mass slab

583 partial melts and diapirs $6,19,33,113$. However, it has recently been suggested that low-mass

584 fractionated slab fluids, added to an enriched, heterogeneous mantle can create similar

585 trace element and isotopic variations as strong subduction enrichment ${ }^{107,124,131}$.

586 Distinguishing between the presence of an inherent enriched component and

587 contribution of recycled eroded crust is complicated ${ }^{107,129}$, owing to the similar

588 composition of the source components involved in each model. For example, inherently

589 enriched mantle (EM) is believed to form through the deep subduction of slab materials

590 beyond the arc volcanic front and their integration into the sources of ocean island

591 basalts $(\mathrm{OIB})^{13,21,25,103}$.

592 EM1 and EM2, the two most common 'flavours' of enriched mantle in OIBs, have been

593 related to the deep recycling of eroded crust $^{24,25,102}$ and sediment ${ }^{13,21}$, respectively

594 (although EM1-type mantle has also been connected with the metasomatised

595 subcontinental lithosphere) $)^{103,107,109,131,211}$. Nd and Hf are largely immobile in slab fluids,

596 but sensitive to contribution of slab materials recycled via partial melts ${ }^{19,33}$ and diapirs ${ }^{5,6}$.

597 As a result, Nd-Hf isotope and trace element systematics should reveal whether EM-

598 type magmas and arc magmas have a common mantle source. In a plot of $\varepsilon N d$ vs. $\varepsilon H f$,

599 arc magmas fall into two groups (Fig. 7). One group, which is represented by only a few

600 arcs (Sunda, Banda, southern Lesser Antilles, and Luzon), forms concave downward

601 mixing trends between a radiogenic, depleted mantle and a low $\varepsilon N d-\varepsilon H f$ crustal end

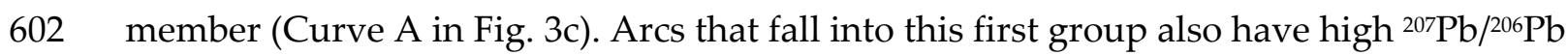

603 ratios (Fig 6a), indicative of sediment recycling. Only clay-rich sediment with a high

$604 \mathrm{Nd} / \mathrm{Hf}>10$ (ref. ${ }^{157}$ ) can re-produce these curved trends $s^{6,19,212,213}$, given that the mantle has 
606 Most arcs, such as the TMVB, Central American arc and the Andean SVZ, form straight 607 arrays in $\varepsilon N d-\varepsilon H f$ space (Fig. 7), which overlap with the composition of EM-type OIBs ${ }^{102}$ 608 and are thus consistent with a common EM-type source ${ }^{107}$. However, the linear arrays 609 displayed in $\varepsilon N d-\varepsilon H f$ space by most arcs can also be explained by slab-mantle mixing in 610 the active subduction regime, provided that the slab components share the low $\mathrm{Nd} / \mathrm{Hf}$ 611 ratio of the mantle ( 5-6). A range of low $\mathrm{Nd} / \mathrm{Hf}$ slab components exist, including 612 terrigenous trench sediment ${ }^{110,157}$, eroded continental rocks ${ }^{214}$, and MORB and OIB-type 613 oceanic crust ${ }^{215,216}$. As the high $\mathrm{Nd} / \mathrm{Hf}$ sediment subgroup ${ }^{14,157}$ has a clear influence on 614 some arc magmas (Curve A on Fig. 7), and must be related to the presence of subduction 615 materials, the 'straight' $\varepsilon N d-\varepsilon H f$ arc trends are also likely to have a subduction origin.

616 The $\varepsilon \mathrm{Nd}-\varepsilon \mathrm{Hf}$ trends observed in arc magma compositions are best revealed from 617 unfiltered arc data. Filtering for mafic arc magmas (that is, those with $\mathrm{MgO}>6 \mathrm{wt} \%$ or $618 \mathrm{Mg} \#>60$ ) would remove $\sim 70 \%$ of the arc $\varepsilon \mathrm{Nd}-\varepsilon H f$ data and thus reduce the clarity of the 619 mixing systematic. Considering unfiltered datasets implicitly assumes that there is no 620 major influence of crustal contamination, consistent with the ${ }^{207} \mathrm{~Pb} / 204 \mathrm{~Pb}$ vs. $\mathrm{SiO}_{2}$ trends 621 (Fig. 6) and supported by the combined ${ }^{3} \mathrm{He} /{ }^{4} \mathrm{He}$ and $\delta^{18} \mathrm{O}$ systematics of the olivines 622 from the TMVB (Fig. 3).

623 Future studies should focus on analysis of the cosmogenic isotope ${ }^{10} \mathrm{Be}$ in arc magmas, 624 as it is the only geochemical tracer that can conclusively distinguish a subduction625 related input from inherent mantle enrichment. ${ }^{10} \mathrm{Be}$ is formed by cosmic ray spallation 626 in the atmosphere ${ }^{30,217}$ and, owing to its short half-life of $1.5 \mathrm{Myr}$, it is enriched in upper 627 marine sediments, but never in the mantle ${ }^{30}$. The presence of measurable ${ }^{10} \mathrm{Be}$ in arc 628 magmas proved sediment recycling beyond doubt ${ }^{10,218} .{ }^{10} \mathrm{Be}$ is expensive and difficult to 629 measure, yet a detection in arcs may allow to test for links between an enrichment and 630 slab processing, at least in those arcs where the transit time from trench to arc remains 631 with the $\leq 6 \mathrm{Myr}$ lifespan of ${ }^{10} \mathrm{Be}\left(\right.$ ref. $\left.^{30}\right)$.

632 The influence of underlying mantle heterogeneity and/or eroded crust on arc magmas 
can also be tested through integrative and comprehensive geochemical analyses of

634 single arc setting. Future studies of arcs and forearcs should make use of the available

635 toolbox of geochemical tracers (that is, major and trace elements and $\mathrm{Sr}-\mathrm{Nd}-\mathrm{Pb}-\mathrm{Hf}-\mathrm{He}-\mathrm{O}-$

636 Os-B-Be isotopes), as well as emerging new isotope tracers, such as ${ }^{238} \mathrm{U} / 235 \mathrm{U}$ (refs. ${ }^{20,219}$ ), ${ }^{205} \mathrm{Tl} /{ }^{203} \mathrm{Tl}\left(\right.$ ref. ${ }^{220}$ ) or ${ }^{138} \mathrm{Ce} /{ }^{142} \mathrm{Ce}$ (ref. ${ }^{221}$ ). Analysis of all end-member materials, including next to trench, forearc and arc lithologies, and rear-arc magmas, which may be considered free from subduction influence while still close enough to the active arc to approximate the regional ambient mantle ${ }^{107,129}$, must be considered. For example, reararc magmas of the $\mathrm{TMVB}^{142,222,223}$ have $\varepsilon \mathrm{Nd}$ values that are too radiogenic to account for systematics of the TMVB are controlled by forearc crust recycling ${ }^{5,6}$. In the Andean SVZ, where rear-arc volcanism is abundant ${ }^{226-228}$, rear-arc and arc front magmas have a similar range in $\varepsilon N d$ vs $\varepsilon H f$ space, which seems to point to common, inherently enriched EMtype mantle source ${ }^{107,129,131}$. However, a larger dataset revealed that the SVZ arc front and rear-arc magmas form two parallel trends in $\varepsilon N d$ vs $\varepsilon H f$ space ${ }^{131}$, which indicates that the arc magmas are also influenced by active subduction recycling ${ }^{107}$.

649 We stress that regional-scale, multidisciplinary studies that integrate geological and 650 geochemical data from the trench, forearc, arc and rear-arc are needed to understand the 651 impact of erosion recycling on volcanic arcs and, ultimately, its role in generating mantle 652 heterogeneity as well as growth and destruction of the continental crust.

\section{REFERENCES}

6541 Huene, R. v. \& Scholl, D. W. Observations at convergent margins concerning 655 sediment subduction, subduction erosion, and the growth of continental crust. 656 Reviews of Geophysics 29, 279-316 (1991).

6572 Huene, R. v., Ranero, C. R. \& Vannucchi, P. Generic model of subduction 658 erosion. Geochim Cosmochim Acta 32, 913-916, doi: 910.1130/G20563.20561 (2004).

6593 Clift, P. D., Vannucchi, P. \& Morgan, J. P. Crustal redistribution, crust-mantle recycling and Phanerozoic evolution of the continental crust. Earth-Science Reviews 97, 80-104, doi:110.1016/j.earscirev.2009.1010.1003 (2009b). implications. Gondwana Res 40, 184-198, dx.doi.org/110.1016/j.gr.2016.1010.1001 
(2016).

5 Parolari, M., Gómez-Tuena, A., Cavazos-Tovar, J. G. \& Hernández-Quevedo, G. A balancing act of crust creation and destruction along the western Mexican convergent margin. Geochim Cosmochim Acta 46, 455-458, doi.org/410.1130/G39972.39971 (2018a).

6 Straub, S. M. et al. Crustal Recycling by Subduction Erosion in the central Mexican Volcanic Belt. Geochimica Cosmochimica Acta 166, 29-52, 10.1016/j.gca.2015.1006.1001 (2015a).

7 Gómez-Tuena, A., Cavazos-Tovar, J. G., Parolari, M., Straub, S. M. \& EspinasaPereña, R. Geochronological and geochemical evidence of continental crust 'relamination' in the origin of intermediate arc magmas. Lithos 322, 52-66, doi.org/10.1016/j.lithos.2018.1010.1005 (2018).

8 Mahlburg Kay, S. M., Godoy, E. \& Kurtz, A. Episodic arc migration, crustal thickening, subduction erosion, and magmatism in the south-central Andes. Geol Soc Am Bull 117, 67-88; doi: 10.1130/B25431.25431 (2005).

9 Kelemen, P. B. \& Behn, M. D. Formation of lower continental crust by relamination of buoyant arc lavas and plutons:. Nature Geoscience 9, 197-205, doi.org /110.1038/ngeo2662. (2016).

10 Morris, J. D., Leeman, W. P. \& Tera, F. The subducted component in island arc lavas: constraints from Be isotopes and B-Be systematics. Nature 344, 31-36 (1990).

11 Plank, T. \& Langmuir, C. H. Tracing trace elements from sediment input to volcanic output at subduction zones. Nature 362, 739-743 (1993).

12 White, W. M. \& Patchett, J. Hf-Nd-Sr isotopes and incompatible element abundances in island arcs: implications for magma origin and crust-mantle evolution. Earth and Planetary Science Letters 67, 167-185 (1984).

13 White, W. M. Probing the Earth's Deep Interior Through Geochemistry. Geochemical Perspectives 4, 95-251 (2015).

14 Plank, T. \& Langmuir, C. H. The geochemical composition of subducting sediment and its consequences for the crust and the mantle. Chem Geol 145, 325394 (1998).

15 Clift, P. D. \& Vannucchi, P. Controls on Tectonic Accretion versus Erosion in Subduction Zones: Implications for the Origin and Recycling of the Continental Crust Reviews of Geophysics 42, RG2001, DOI: 2010.1029/2003RG000127. (2004).

16 Scholl, D. W. \& Huene, R. v. in 4-D Framework of Continental Crust: Vol. 200 (eds R D Jr Hatcher, M P Carlson, J H McBride, \& J R Martínez Catalán) 9-32, doi: 10.1130/2007.1200(1102). (Geological Society of America Memoir 2007).

17 Kay, R. W., Sun, S. S. \& Lee-Hu, C. N. Pb and Sr isotopes in volcanic rocks from the Aleutian Islands and Pribilof Islands, Alaska. Geochim Cosmochim Acta 42, 263-273 (1978).

18 Chauvel, C., Lewin, E., Carpentier, M., Arndt, N. T. \& Marini, J. C. Role of recycled oceanic basalt and sediment in generating the Hf-Nd mantle array. Nature Geosciences 1, doi:10.1038/ngeo.2007.1051 (2008).

19 Chauvel, C., Marini, J. C., Plank, T. \& Ludden, J. N. Hf-Nd input flux in the IzuMariana subduction zone and recycling of subducted material in the mantle. Geochem Geophys Geosys 10, doi:10.1029/2008GC002101 (2009).

20 Andersen, M. B. et al. The terrestrial uranium isotope cycle. Nature 517, 256-359, 
doi:210.1038/nature14062 (2015).

71221 Hofmann, A. W. in Treatise on Geochemistry Vol. 2 (eds H D Holland, K K Turekian, \& R W Carlson) 61-101, ISBN 100-108-043751-043756 (Elsevier, 2003).

Sobolev, A. V. et al. The Amount of Recycled Crust in Sources of Mantle-Derived Melts. Science 316, 412-417, 410.1126/science.1138113 (2007).

Stern, C. R. Subduction erosion: Rates, mechanisms, and its role in arc magmatism and the evolution of the continental crust and mantle. Gondwana Res 20, 284-308, doi:210.1016/j.gr.2011.1003.1006 (2011).

Willbold, M. \& Stracke, A. Trace element composition of mantle end-members: Implications for recycling of oceanic and upper and lower continental crust. Geochem Geophys Geosyst 7, Q04004, doi:04010.01029/02005GC001005 (2006).

Stracke, A. Earth's heterogeneous mantle: A product of convection-driven interaction between crust and mantle. Chem Geol 330-331, 274-299, doi.org/210.1016/j.chemgeo.2012.1008.1007 (2012).

26 Vannucchi, P., Scholl, D. W., Meschede, M. \& McDougall-Reid, K. Tectonic erosion and consequent collapse of the Pacific margin of Costa Rica: Combined implications from ODP Leg 170, seismic offshore data and regional geology of the Nicoya Peninsula Tectonics, 20, 649-668 (2001).

27 Vannucchi, P. et al. Fast rates of subduction erosion along the Costa Rica Pacific margin: Implications for nonsteady rates of crustal recycling at subduction zones. J Geophys Res 108, 2511, 2510.1029/2002JB002207 (2003).

28 Ranero, C. R. \& Huene, R. v. Subduction erosion along the Middle American convergent margin. Nature 404, 748-752 (2000).

29 Vannucchi, P., Galeotti, S., Clift, P. D., Ranero, C. R. \& Huene, R. v. Long-term subduction-erosion long the Guatemalan margin of the Middle American Trench. Geochim Cosmochim Acta 32, 617-620 (2004).

30 Morris, J. D., Gosse, J., Brachfeld, S. \& Tera, F. in Reviews in Mineralogy Vol. 50 (ed E Grew) 207-270 (Mineralogical Society of America, Washington, DC, 2002).

31 Miller, D. M., Goldstein, S. L. \& Langmuir, C. H. Cerium/lead and lead isotope ratios in arc magmas and the enrichment of lead in the continents. Nature 368, 514-520 (1994).

32 Kelemen, P. B., Hanghoi, K. \& Greene, A. R. in The Crust (ed. RL Rudnick) Vol. 3, Treatise on Geochemistry Vol. 3 (eds HD Holland \& KK Turekian) 593-659 (Elsevier-Pergamon, 2004).

33 Elliott, T., Plank, T., Zindler, A., White, W. \& Bourdon, B. Element transport from subducted slab to juvenile crust at the Mariana arc. J Geophys Res 102, 1499115019 (1997).

34 Nielsen, S. G. \& Marschall, H. R. Geochemical evidence for mélange melting in global arcs. Science Advances 3, 1602402, doi.org /1602410.1601126 /sciadv.1602402 (2017).

35 Yogodzinski, G. M., Vervoort, J. D., Brown, S. T. \& Gerseny, M. Subduction controls of $\mathrm{Hf}$ and $\mathrm{Nd}$ isotopes in lavas of the Aleutian island arc. Earth Planet Sci Lett 300 226-238, doi:210.1016/j.epsl.2010.1009.1035 (2010).

36 Yogodzinski, G. M. et al. The Role of Subducted Basalt in the Source of Island Arc Magmas: Evidence from Seafloor Lavas of the Western Aleutians. J Petrol 56, 441492, doi: 410.1093/petrology/egv1006 (2015). 
Castillo, P. R., Lonsdale, P. F., Moran, C. L. \& Hawkins, J. W. Geochemistry of mid-Cretaceous Pacific crust being subducted along the Tonga-Kermadec Trench: Implications for the generation of arc lavas. Lithos 112, 87-102, doi:110.1016/j.lithos.2009.1003.1041 (2009).

38 Kendrick, M. A. et al. Subduction-related halogens $(\mathrm{Cl}, \mathrm{Br}$ and $\mathrm{I})$ and $\mathrm{H}_{2} \mathrm{O}$ in magmatic glasses from Southwest Pacific Backarc Basins. Earth Planet Sci Lett 400, 165-176, http://dx.doi.org/110.1016/j.epsl.2014.1005.1021 (2014).

39 Barnes, J. D., Sharp, Z. D. \& Fischer, T. P. Chlorine isotope variations across the Izu-Bonin-Mariana arc. Geochim Cosmochim Acta 36, 883-886; doi: 810.1130/G25182A (2008).

40 Barnes, J. D. \& Straub, S. M. Chlorine stable isotope variations in Izu Bonin tephra: Implications for serpentinite subduction. Chemical Geology 272, 62-74, doi:10.1016/j.chemgeo.2010.1002.1005 (2010).

41 Hildreth, W. \& Moorbath, S. Crustal contributions to arc magmatism in the Andes of Central Chile. Contrib Mineral Petrol 98, 455-489 (1988).

Seely, D. R., Vail, P. R. \& Walton, G. O. in The Geology of Continental Margins (eds C A Burk \& C L Drake) 249- 260 (Springer-Verlag 1974).

43 Karig, D. E. Tectonic Erosion at Trenches. Earth Planet Sci Lett 21, 209-212 (1974).

Karig, D. E. \& Sharman, G. F. Subduction and accretion in trenches. Earth Planet Sci Lett 86, 377-389 (1975).

Dickinson, W. R. Plate tectonics in geologic history Science 174, 107-113 (1971).

Hussong, D. M., Edwards, P. B., Johnson, S. H., Campbell, J. F. \& Sutton, O. H. in The Geophysics of the Pacific: Ocean Basin and its Margin Vol. 19 Geophys Monograph Series (eds O H Sutton, M H Manghani, \& R Moberly) 71-85 (AGU 1976).

Scholl, D. W., Huene, R. v., Vallier, T. L. \& Howell, D. G. Sedimentary masses and concepts about tectonic processes at underthrust ocean margins Geochim Cosmochim Acta 8, 564-568 (1980). \\ Tatsumi, Y. \& Eggins, E. Subduction Zone Magmatism. (Blackwell Science, 1995).}

Vannucchi, P. et al. Past seismic slip-to-the-trench recorded in Central America megathrust. Nature Geoscience 10, 935-940, doi:10.1038/s41561-017-0013-4 (2017).

Kessel, R., Schmidt, M. W., Ulmer, P.\& Pettke, T. Trace element signature of subduction-zone fluids, melts and supercritical liquids at 120-180 km depth. Nature 437, 724-727, doi:710.1038/nature03971 (2005).

52 Marschall, H. R. \& Schumacher, J. C. Arc magmas sourced from mélange diapirs in subduction zones. Nat Geoscience 5, 862-867, doi: 810.1038/NGEO1634 (2012).

53 Gerya, T. V., Yuen, D. A. \& Sevre, E. O. D. Dynamical causes for incipient magma chambers above slabs. Geochim Cosmochim Acta 32, 89-92, doi:10.1130/G20018.20011 (2004).

54 Mibe, K., Kawamoto, T., Matsukage, K. N., Fei, Y. \& Ono, S. Slab melting versus slab dehydration in subduction-zone magmatism. PNAS 108 8177-8182 (2011).

55 Cruz-Uribe, A. M., Marschall, H. R., Gaetani, G. A. \& Le Roux, V. Generation of alkaline magmas in subduction zones by partial melting of mélange diapirs-An 
experimental study. Geochim Cosmochim Acta 46, 343-346, doi.org/310.1130/G39956.39951 (2018).

56

Codillo, E. A., Le Roux, V. \& Marschall, H. R. Arc-like magmas generated by mélange-peridotite interaction in the mantle wedge. Nat Comm 9, 2864 , doi: 2810.1038/s41467-41018-05313-41462 (2018).

57 Scholl, D. W. \& Huene, R. v. in Earth Accretionary Systems in Space and Time Vol. 318 (eds P A Cawood \& A Kroener) 105-125, doi: 110.1144/SP1318.1144 (The Geological Society, Special Publications 2009, London, 2009).

58 Clift, P., Schouten, H. \& Vannucchi, P. in Accretionary Orogens in Space and Time Vol. 318 (eds P Cawood \& A Kroener) 75-103 (Geological Society, 2009a).

59 Stern, R. J. \& Scholl, D. W. Yin and yang of continental crust creation and destruction by plate tectonic processes. International Geology Review, 1-31, doi: 10.1080/00206810903332322 (2010).

60 Rutland, R. W. R. Andean Orogeny and Ocean Floor Spreading. Nature 233, 252255 (1971).

61 Ziegler, A. M., Barrett, S. F., Scotese, C. R. \& Sellwood, B. W. Palaeoclimate, Sedimentation and Continental Accretion [and Discussion]. Philosophical Transactions of the Royal Society of London, Series A 301, 253-264, 253w.jstor.org/stable/37016 (1981).

62 Miller, H. Das Problem des hypothetischen "pazifischen Kontinentes" gesehen von der chilenischen Pazifikkueste. Geologische Rundschau 59, 927-938 (1970a).

63 Miller, H. Vergleichende Studie an prae-mesozoischen Gesteinen Chiles unter besonderer Beruecksichtigung ihrer Kleintektonik. Geotek Forsch 36 1- 64 (1970b).

64 Murauchi, J. in The Ocean World Vol. 303-305 (ed M Uda) 1971 (Proc Joint Oceanogr Assembly, 1971).

65 Bangs, N. L. B., Gulick, S. P. S. \& Shipley, T. H. Seamount subduction erosion in the Nankai Trough and its potential impact on the seismogenic zone. Geochim Cosmochim Acta 34 701-704, doi: 710.1130/G22451.22451. (2006 ).

66 Huene, R. v. \& Lallemand, S. Tectonic erosion along the Japan and Peru convergent margins. Geol Soc Am Bull 102, 704-720, doi.org/710.1130/00167606(1990)1102<0704:TEATJA>1132.1133.CO;1132 (1990).

67 Schaaf, P. et al. Paleogene continental margin truncation in southwestern Mexico: Geochronological evidence. Tectonics 14, 1339-1350 (1995).

68 Morán-Zenteno, D. J. et al. Cenozoic magmatism of the Sierra Madre del Sur and tectonic truncation of the Pacific margin of southern Mexico:. Earth-Science Reviews 183, 85-114, doi:110.1016/j.earscirev.2017.1001.1010. (2018).

69 Isozaki, Y., Aoki, K., Nakama, T. \& Yanai, S. New insight into a subductionrelated orogen: a reappraisal of the geotectonic framework and evolution of the Japanese Islands. Gondwana Res. 18, 82-105 (2010).

70 Hussong, D. M. \& Uyeda, S. in Init Repts DSDP 60 Vol. 60 (eds D M Hussong \& S Uyeda) 909-929 (Washington (U.S. Govt. Printing Office), 1982).

71 Seely, D. R. \& Dickinson, W. R. in Geology of Continental Margins Vol. 5 (eds J R Curray et al.) 1-22 (American Association of Petroleum Geologists, 1977).

72 Dickinson, W. R. \& Seely, D. R. Structure and stratigraphy of forearc regions. Bull Am Ass Petrol Geol 63, 2-31 (1979). 
Karig, D. E., Caldwell, J. G. \& Paramentier, E. M. Effects of accretion on the geometry of the descending lithosphere. J Geophys Res 81, 6281-6291 (1976).

74 Dickinson, W. R. in Tectonics of Sedimentary Basins (eds C.J Busby \& R V Ingersoll) 221-261 (Blackwell Science, 1995).

75 Fuller, C. W., Willett, S. D. \& Brandon, M. T. Formation of forearc basins and their influence on subduction zone earthquakes. Geochim Cosmochim Acta 34 6568, doi:10.1130/G21828.21821. (2006).

76 Noda, A. Forearc basins: Types, geometries, and relationships to subduction zone dynamics. Geol Soc Am Bull 128, 879-889 (2016).

77 Huene, R. v. \& Culotta, R. Tectonic erosion at the front of the Japan Trench convergent margin. Tectonophysics 160, 75-90, doi.org/10.1016/00401951(1089)90385-90385 (1989).

78 Boston, B., Moore, G. F., Nakamura, Y. \& Kodaira, S. Forearc slope deformation above the Japan Trench megathrust: Implications for subduction erosion. Earth Planet Sci Lett 462, doi.org/10.1016/j.eps1.2017.01.005, 26-34 (2017).

79 Regalla, C., Fisher, D. M., Kirby, E. \& Furlong, K. P. Relationship between outer forearc subsidence and plate boundary kinematics along the Northeast Japan convergent margin. Geochemistry, Geophysics, Geosystems 14, 5227-5243, doi:10.1002/2013gc005008 (2013).

80 Regalla, C., Fisher, D. M., Kirby, E., Oakley, D. \& Taylor, S. Slip Inversion Along Inner Fore-Arc Faults, Eastern Tohoku, Japan. Tectonics 36, 2647-2668, doi:10.1002/2017tc004766 (2017).

81 Ranero, C. R. et al. Hydrogeological system of erosional convergent margins and its influence on tectonics and interplate seismogenesis. Geochem Geophys Geosys 9, Q03S04, doi:10.1029/2007GC001679. (2008).

82 Sallarès, V., Charvis, P., Flueh, E. R. \& Bialas, J. Seismic structure of Cocos and Malpelo Volcanic Ridges and implications for hot spot-ridge interaction. Journal of Geophysical Research: Solid Earth 108, doi:10.1029/2003jb002431 (2003).

83 Vannucchi, P. et al. Rapid pulses of uplift, subsidence, and subduction erosion offshore Central America: Implications for building the rock record of convergent margins. Geochim Cosmochim Acta 41, 995-998, doi:910.1130/G34355.34351 | (2013).

84 Morell, K. D., Fisher, D. M. \& Bangs, N. Plio-Quaternary Outer Forearc Deformation and Mass Balance of the Southern Costa Rica Convergent Margin. Journal of Geophysical Research: Solid Earth 124, 9795-9815, 9710.1029/2019jb017986 (2019).

85 Riedinger, N. et al. Interplay of Subduction Tectonics, Sedimentation, and Carbon Cycling. Geochemistry, Geophysics, Geosystems 20, 4939-4955, doi:10.1029/2019gc008613 (2019).

86 Zeumann, S. \& Hampel, A. Deformation of erosive and accretive forearcs during subduction of migrating and non-migrating aseismic ridges: Results from 3-D finite element models and application to the Central American, Peruvian, and Ryukyu margins. Tectonics 34, 1769-1791, doi:10.1002/2015tc003867 (2015).

87 Edwards, J. H., Kluesner, J. W., Silver, E. A. \& Bangs, N. L. Pleistocene vertical motions of the Costa Rican outer forearc from subducting topography and a migrating fracture zone triple junction. Geosphere 14, 510-534, 510.1130/ges01577.01571 (2018). 
88 Ranero, C. R. \& Sallares, V. Geophysical evidence for hydration of the crust and mantle of the Nazca plate during bending at the north Chile trench. Geochim Cosmochim Acta 32, 549-552 (2004).

89 Hensen, C., Wallmann, K., Schmidt, M., Ranero, C. R. \& Suess, E. Fluid expulsion related to mud extrusion off Costa Rica - A window to the subducting slab:. Geochim Cosmochim Acta 32, 201-204, doi: 210.1130/G20119.20111 (2004).

90 Vannucchi, P., Sage, F., Morgan, J. P., Remitti, F. \& Collot, J. Y. Toward a dynamic concept of the subduction channel at erosive convergent margins with implications for interplate material transfer. Geochem Geophys Geosys v. 13, Q02003, doi:10.1029/2011GC003846. (2012).

91 Cloos, M. \& Shreve, R. L. Subduction-channel model of prism accretion, melange formation, sediment subduction, and subduction erosion at convergent plate margins: 1. Background and description. Pure and Applied Geophysics, 128 456-500 (1988a).

92 Cloos, M. \& Shreve, R. L. Subduction-channel model of prism accretion, melange formation, sediment subduction, and subduction erosion at convergent plate margins. 2. Implications and discussion. Pure and Applied Geophysics 128, 501-545 (1988b).

93 Clift, P. D. \& Hartley, A. Slow rates of subduction erosion along the Andean margin and reduced global crustal recycling Geochim Cosmochim Acta 35, 503-506 (2007).

94 Sutherland, R. et al. Reactivation of tectonics, crustal underplating, and uplift after 60 Myr of passive subsidence, Raukumara Basin, Hikurangi-Kermadec forearc, New Zealand: implications for global growth and recycling of continents. Tectonics 28, TC5017. doi: 5010.1029/ 2008TC002356 (2009).

Scholl, D. W. Seismic imaging evidence that forearc underplating built the accretionary rock record of coastal North and South America. Geological Magazine doi.org/10.1017/S0016756819000955 (2019).

96 Polonia, A., Torelli, L., Brancolini, G. \& Loreto, M. F. Tectonic accretion versus erosion along the southern Chile trench: Oblique subduction and margin segmentation. Tectonics 26, TC3005, 3010.1029/2006tc001983 (2007).

97 Bassett, D. et al. Three-dimensional velocity structure of the northern Hikurangi margin, Raukumara, New Zealand: implications for the growth of continental crust by subduction erosion and tectonic underplating.. Geochem Geophys Geosys 11, Q10013, doi: 10010. 11029/12010GC003137. (2010).

98 Bangs, N. L., Christeson, G. L. \& Shipley, T. H. Structure of the Lesser Antilles subduction zone backstop and its role in a large accretionary system. J Geophys Res 108, 2358, doi:2310.1029/2002JB002040 (2003).

99 Armstrong, R. L. Radiogenic isotopes: the case for crustal recyling in a nearsteady-state no-continental-growth Earth. Phil Trans R Soc Lond A 301, 443-472 (1981).

100 Vervoort, J. D. \& Blichert-Toft, J. Evolution of the depleted mantle: Hf isotope evidence from juvenile rocks through time. Geochim Cosmochim Acta 63, 533-556 (1999).

101 Bouvier, A., Vervoort, J. D. \& Patchett, P. J. The Lu-Hf and Sm-Nd isotopic composition of CHUR: Constraints from unequilibrated chondrites and implications for the bulk composition of terrestrial planets. Earth Planet Sci Lett 
273, doi:10.1016/j.eps1.2008.06.010, 48-57 (2008).

942

943

944

945

946

947

948

949

950

951

952

953

954

955

956

957

958

959

960

961

962

963

964

965

966

967

968

969

970

971

972

973

974

975

976

977

978

979

980

981

982

983

984

985

986

102 Willbold, M. \& Stracke, A. Formation of enriched mantle components by recycling of upper and lower continental crust. Chem Geol 276, 188-197, doi:110.1016/j.chemgeo.2010.1006.1005 (2010).

103 Workman, R. K. et al. Recycled metasomatized lithosphere as the origin of the Enriched Mantle II (EM2) end-member: Evidence from the Samoan Volcanic Chain. Geochem Geophys Geosys 5, Q04008, doi:04010.01029/02003GC000623 (2004).

104 Kelley, K. A., Plank, T., Farr, L., Ludden, J. \& Staudigel, H. Subduction cycling of U, Th, and Pb. Earth Planet Sci Lett 234, 369-383 (2005).

105 Annen, C., Blundy, J. D. \& Sparks, R. S. J. The Genesis of Intermediate and Silicic Magmas in Deep Crustal Hot Zones. J Petrol 47, 505-539, doi:510.1093/petrology/egi1084 (2006).

106 Perfit, M. R., Gust, D. A., Bence, A. E., Arculus, R. J. \& Taylor, S. R. Chemical characteristics of island-arc basalts:implications for mantle sources. Chemical Geology 30, 227-256 (1980).

107 Turner, S. J., Langmuir, C. H., Dungan, M. A. \& Escrig, S. The importance of mantle wedge heterogeneity to subduction zone magmatism and the origin of EM1. Earth Planet Sci Lett 472, 216-228, dx.doi.org/210.1016/j.epsl.2017.1004.1051 (2017).

108 Hawkesworth, C. J., Gallagher, K., Hergt, J. M. \& McDermott, F. Mantle and slab contributions in arc magmas. Annu Rev Earth Planet Sci 21, 175-204 (1993).

109 Rogers, G. \& Hawkesworth, C. J. A geochemical traverse across the North Chilean Andes: evidence for crust generation from the mantle wedge. Earth Plant Sci Lett 91, 271-285 (1989).

110 Vervoort, J. D., Plank, T. \& Prytulak, J. The Hf-Nd isotopic composition of marine sediments. Geochimica et Cosmochimica Acta 75, 5903-5926, doi:5910.1016/j.gca.2011.5907.5046 (2011).

111 Ludden, J. N., Plank, T., Larson, R. \& Escutia, C. in Proceedings of the Ocean Drilling Program, Sci Res Vol. 185 (eds J N Ludden, T Plank, \& C Escutia) doi:10.2973/odp.proc.sr.2185.2014.2006 (Ocean Drilling Program, 2006).

112 Contreras-Reyes, E. in The Evolution of the Chilean-Argentinean Andes (eds Folguera A et al.) 3-29, doi:doi.org/10.1007/1978-1003-1319-67774-67773_67771 (Springer Earth System Sciences, 2018).

113 Holm, P. M., Søager, N., Thorup Dyhr, C. \& Rohde Nielsen, M. Enrichments of the mantle sources beneath the Southern Volcanic Zone (Andes) by fluids and melts derived from abraded upper continental crust. Contrib Mineral Petrol 167, 1004, DOI 1010.1007/s00410-00014-01004-00418 (2014).

114 Stern, C. R. Role of subduction erosion in the generation of Andean magmas. Geochim Cosmochim Acta 19, 78-81 (1991).

115 Mahlburg Kay, S., Mpodozis, C. \& Gardeweg, M. in Orogenic Andesites and Crustal Growth Vol. 385 (eds A Gomez-Tuena, S M Straub, \& G F Zellmer) 303334, dx.doi.org/310.1144/SP1385.1111 (Geological Society of London, 2014).

116 Goss, A. R., Mahlburg Kay, S. \& Mpodozis, C. Andean adakite-like high-Mg andesites on the Northern margin of the Chilean-Pampean flat-slab (27-28.58 S) associated with frontal arc migration and fore-arc subduction erosion. J Petrol 54, 


\begin{tabular}{|c|c|c|}
\hline 987 & & \\
\hline $\begin{array}{l}988 \\
989 \\
990\end{array}$ & 117 & $\begin{array}{l}\text { Goss, A. R. \& Kay, S. M. Extreme high field strength element (HFSE) depletion } \\
\text { and near-chondritic Nb/Ta ratios in Central Andean adakite-like lavas ( } 28^{\circ} \mathrm{S} \text {, } \\
\left.-68^{\circ} \mathrm{W}\right) \text {. Earth Planet Sci Lett } 279,97-109(2009) \text {. }\end{array}$ \\
\hline $\begin{array}{l}991 \\
992 \\
993\end{array}$ & 8 & $\begin{array}{l}\text { Mahlburg Kay, S. \& Mpodozis, C. Magmatism as a probe of Neogene shallowing } \\
\text { of the Nazca Plate beneath the modern Chilean flat-slab Journal of South American } \\
\text { Earth Sciences 15, 39-57. 10.1016/S0895-9811(1002)00005-00006. (2002). }\end{array}$ \\
\hline $\begin{array}{l}994 \\
995 \\
996\end{array}$ & 119 & $\begin{array}{l}\text { Jicha, B. R. \& Mahlburg Kay, S. Quantifying arc migration and the role of forearc } \\
\text { subduction erosion in the central Aleutians. J Volcanol Geotherm Res 360, 84-99, } \\
\text { doi.org/10.1016/j.jvolgeores.2018.1006.1016 (2018). }\end{array}$ \\
\hline $\begin{array}{l}997 \\
998 \\
999\end{array}$ & 20 & $\begin{array}{l}\text { Mahlburg Kay, S. et al. The Calc-alkaline Hidden Bay and Kagalaska Plutons and } \\
\text { the Construction of the Central Aleutian Oceanic Arc Crust. J Petrol 60, 393-439, } \\
\text { doi: 310.1093/petrology/egy1119 (2019). }\end{array}$ \\
\hline $\begin{array}{l}000 \\
001 \\
002\end{array}$ & 121 & $\begin{array}{l}\text { Karlstrom, L., Lee, C. T. A. \& Manga, M. The role of mag } \\
\text { lithospheric thickening on arc front migration. Geochemis }\end{array}$ \\
\hline $\begin{array}{l}003 \\
004 \\
005\end{array}$ & 2 & $\begin{array}{l}\text { Giambiagi, L. et al. in Geodynamic Processes in the Andes of Central Chile and } \\
\text { Argentina Vol. } 399 \text { (eds S A Sepúlveda et al.) 63, dx.doi.org/10.1144/SP1399.1114 } \\
\text { (Geological Society of London Special Publications, 2015). }\end{array}$ \\
\hline $\begin{array}{l}1006 \\
1007 \\
1008 \\
1009\end{array}$ & 123 & $\begin{array}{l}\text { Holm, P. M., Søager, S., Alfastsen, M. \& Bertotto, G. W. Subduction zone mantle } \\
\text { enrichment by fluids and Zr-Hf-depleted crustal melts as indicated by backarc } \\
\text { basalts of the Southern Volcanic Zone, Argentina. Lithos 262,135-152, } \\
\text { http://dx.doi.org/110.1016/j.lithos.2016.1006.1029 (2016). }\end{array}$ \\
\hline 1012 & 4 & $\begin{array}{l}\text { Wieser, P. E. et al. New constraints from Central Chile on the origins of enriched } \\
\text { continental compositions in thick-crusted arc magmas. Geochim Cosmochim Acta } \\
\text { 267,51-74, doi.org/10.1016/j.gca.2019.1009.1008 (2019). }\end{array}$ \\
\hline $\begin{array}{l}101 \\
101\end{array}$ & 125 & $\begin{array}{l}\text { Mahlburg Kay, S., Mpodozis, C., Coira, B. \& Skinner, B. J. in Geology and Ore } \\
\text { Deposits of the Central Andes Vol. } 7 \text { 27-59, doi: 10.5382/sp.5307.5302 (Society of } \\
\text { Economic Geologists, 1999). }\end{array}$ \\
\hline $\begin{array}{l}1016 \\
1017\end{array}$ & 26 & $\begin{array}{l}\text { Ramos, V. A. The Grenville-age basement of the Andes. J S Am Earth Sci 29, 77-91 } \\
\text { (2010). }\end{array}$ \\
\hline $\begin{array}{l}1018 \\
1019\end{array}$ & 127 & $\begin{array}{l}\text { Woerner, G., Moorbath, S. \& Harmon, R. S. Andear } \\
\text { reflect basement isotopic remains. Geochim Cosmoch }\end{array}$ \\
\hline $\begin{array}{l}1020 \\
1021\end{array}$ & 28 & $\begin{array}{l}\text { van Keken, P. E. et al. A community benchmark for subduction zone modeling.. } \\
\text { Phys Earth Planet Inter } \mathbf{1 7 1} 187-197 \text { (2008). }\end{array}$ \\
\hline $\begin{array}{l}102 \\
102 \\
102\end{array}$ & 129 & $\begin{array}{l}\text { Turner, S. J. \& Langmuir, C. H. What processes control the chemical } \\
\text { compositions of arc front stratovolcanoes? Geochem Geophys Geosys 16, } \\
\text { doi:10.1002/2014GC005633. (2015b). }\end{array}$ \\
\hline & 130 & $\begin{array}{l}\text { Turner, S. J., Langmuir, C. H., Katz, R. F., Dungan, M. A. \& Escrig, S. Parental arc } \\
\text { magma compositions dominantly controlled by mantle-wedge thermal structure. } \\
\text { Nat Geoscience, DOI: 10.1038/NGEO2788 (2016). }\end{array}$ \\
\hline $\begin{array}{l}102 \\
102 \\
103 \\
103\end{array}$ & 131 & $\begin{array}{l}\text { Jacques, G. et al. Across-arc geochemical variations in the Southern Volcanic } \\
\text { Zone, Chile (34.5-38.0S): Constraints on mantle wedge and slab input } \\
\text { compositions. Geochimica Cosmochimica Acta 123, 218-243, } \\
\text { doi.org/210.1016/j.gca.2013.1005.1016 (2013). }\end{array}$ \\
\hline & 102 & Vannucchi, P., Morgan, J. P., Silver, E. A. \& Kluesner, J. W. Origin and dynamic \\
\hline
\end{tabular}


of depositionary subduction margins Geochem Geophys Geosyst 17, 1966-1974, doi:1910.1002/2016GC006259. (2016).

133 Schindlbeck, J. C. et al. Late Cenozoic Tephrostratigraphy Offshore Southern Central America: 2. Implications for magma subduction rates and subduction erosion. Geochem Geophys Geosys 17, 4585-4604, doi:4510.1002/2016GC006504 (2016b).

134 Gazel, E. et al. The Galapagos-OIB signature in southern Central America: Mantle refertilization by arc-hot spot interaction. Geochem Geophys Geosys 10, Q02S11, doi:10.1029/2008GC002246 (2009).

135 Goss, A. R. \& Kay, S. M. Steep REE patterns and enriched Pb isotopes in southern Central American arc magmas: Evidence for forearc subduction erosion? Geochem Geophys Geosys 7, Q05016, doi:05010.01029/02005GC001163 (2006).

136 Herrstrom, E. A., Reagan, M. K. \& Morris, J. D. Variations in lava composition associated with flow of asthenosphere beneath southern Central America. Geochim Cosmochim Acta 23, 617-620 (1995).

137 Abratis, M. \& Woerner, G. Ridge collision, slab-window formation, and the flux of Pacific asthenosphere into the Caribbean realm. Geochim Cosmochim Acta 29, 127-130, doi:110.1130/0091-7613(2001)1029<0127:RCSWFA>1132.1130.CO;1132. (2001).

138 Feigenson, M. D., Carr, M. J., Maharaj, S. V., Juliano, S. \& Bolge, L. Lead isotopic compositions of Central American volcanoes: Influence of the Galapagos plume. Geochem Geophys Geosys 5, Q06001, doi:101029/102003GC000621 (2004).

139 Gazel, E. et al. Continental crust generated in oceanic arcs. Nat Geoscience 8, doi:321-327, doi 10.1038/NGEO2392 (2015).

140 Gómez-Tuena, A., Mori, L. \& Straub, S. M. Geochemical and petrological insights into the tectonic origin of the Transmexican Volcanic Belt. Earth Science Reviews 183, 153-181, doi:110.1016/j.earscirev. 2016.1012.1006 (2018).

141 Gómez-Tuena, A., Díaz-Bravo, B., Vázquez-Duarte, A., Pérez-Arvizu, O. \& Laura Mori, L. in Orogenic Andesite and Crustal Growth Vol. 385 (eds A Gomez-Tuena, S M Straub, \& G F Zellmer) 65-101, doi 110.1144/SP1385.1144 (Geological Society of London Special Publication, 2014).

142 Gómez-Tuena, A. et al. Temporal control of subduction magmatism in the eastern Trans-Mexican Volcanic Belt: Mantle sources, slab contributions, and crustal contamination. Geochem Geophys Geosys 8, 8913, doi:8910.1029/2002GC000421 (2003).

143 Morán-Zenteno, D. J., Corona-Chavez, P. \& Tolson, G. Uplift and subduction erosion in southwestern Mexico since the Oligocene: pluton geobarometry constraints. Earth Planet Sci Lett 141, 51-65, doi: 10.1016/0012-1821X(1096)0006700062. (1996).

144 Keppie, D. F., Hynes, A. J., Lee, J. K. W. \& Norman, M. Oligocene-Miocene backthrusting in southern Mexico linked to the rapid subduction erosion of a large forearc block. Tectonics 31, TC2008, doi:2010.1029/2011TC002976 (2012).

145 Ducea, M. N. et al. Rates of sediment recycling beneath the Acapulco trench: Constraints from (U-Th)//He thermochronology. J Geophys Res 109, B09404, doi:09410.01029/02004JB003112 (2004).

146 Cavazos-Tovar, J. G., Gómez-Tuena, A. \& Parolari, M. The origin and evolution of the Mexican Cordillera as registered in modern detrital zircons. Gondwana Res 
86, 83-102, doi.org/110.1016/j.gr.2020.1006.1001 (2020).

147 Pindell, J. L. et al. A plate-kinematic framework for models of Caribbean evolution. Tectonophysics "18th Geodynamics Symposium, "Mesozoic and Cenozoic Plate Reconstructions" 55, 121-138, doi.org/110.1016/0040-1951(1088)90262-90264 (1988).

148 Rogers, R. D., Mann, P. \& Emmet, P. A. Tectonic terranes of the Chortis block based on integration of regional aeromagnetic and geologic data Geological Society of America Special Papers 428 65-88, doi.org/10.1130/2007.2428(1104) (2007).

149 Ferrari, L. et al. Late Cretaceous-Oligocene magmatic record in southern Mexico: The case for a temporal slab window along the evolving Caribbean-North America-Farallon triple boundary. Tectonics 33, 1738-1765, doi:1710.1002/2014TC003525 (2014).

150 Silva-Romo, G. et al. Timing of the Cenozoic basins of Southern Mexico and its relationship with the Pacific truncation process: Subduction erosion or detachment of the Chortís block. Journal of South American Earth Sciences 83, 178194, doi.org/110.1016/j.jsames.2018.1001.1007 (2018).

151 Straub, S. M. et al. Formation of hybrid arc andesites beneath thick continental crust. Earth Planet Sci Lett 303, 337-347, doi:310.1016/j.epsl.2011.1001.1013 (2011).

152 Wallace, P. J. \& Carmichael, I. S. E. Quaternary volcanism near the Valley of Mexico: implications for subduction zone magmatism and the effects of crustal thickness variations on primitive magma compositions. Contrib Mineral Petrol 135, 291-314 (1999).

153 Rasoazanamparany, C. et al. Temporal and Compositional Evolution of Jorullo Volcano, Mexico: Implications for Magmatic Processes Associated with a Monogenetic Eruption. Chem Geol 434, 62-80 (2016).

154 Ortega-Gutiérrez, F., Martiny, B. M., Morán-Zenteno, D. J., Reyes-Salas, A. M. \& Solé-Viñas, J. Petrology of very high temperature crustal xenoliths in the Puente Negro intrusion: a sapphire-spinel-bearing Oligocene andesite, Mixteco terrane, southern Mexico. Revista Mexicana de Ciencias Geológicas 28, 593-629 (2011).

155 Ortega-Gutiérrez, F. et al. Petrology of high-grade crustal xenoliths in the Chalcatzingo Miocene subvolcanic field, southern Mexico: buried basement of the Guerrero-Morelos platform and tectonostratigraphic implications. Int Geology Review 54, 1597-1634, http://dx.doi.org/1510.1080/00206814.00202011.00649956 (2012).

156 Ortega-Gutiérrez, F., Gómez-Tuena, A., Elías-Herrera, M., Reyes-Salas, M. \& Macías-Romo, C. Petrology and geochemistry of the Valle de Santiago lowercrust xenoliths: Young tectonothermal processes beneath the central TransMexican volcanic belt. Lithosphere in press, doi: 10.1130/L1317.1131 (2014).

157 Plank, T. in Treatise on Geochemistry (Second Edition) Vol. 4 The Crust (eds H Holland \& K Turekian) 607-629 (Elsevier, 2014).

158 Keppie, J. D., Dostal, J., Murphy, J. B. \& Nance, R. D. in Tectonophysics, The Foundations and Birth of the Rheic Ocean: Avalonian-Cadomian Orogenic Processes and Early Palaeozoic Rifting at the Northern Gondwana Margin / Evolution and Closure of the Rheic Ocean: Palaeozoic Drift of Peri-Gondwanan Terranes and Alleghenian-Variscan Orogenic Processes Vol. 461, (eds M F Pereira, E Bozkurt, R Strachan, \& C Quesada) 277-290, doi.org/210.1016/j.tecto.2008.1001.1012 (2008).

159 Ranero, C. R., Vannucchi, P., Huene, R. v. \& proponents, C. Drilling the 
Seismogenic Zone of an Erosional Convergent Margin: IODP Costa Rica Seismogenesis Project CRISP. Scientific Drilling Special Issue 1, 51-54, doi:10.22 04/iodp.sd.s01.29.2007 (2007).

160 Straub, S. M., LaGatta, A. B., Martin-Del Pozzo, A. L. \& Langmuir, C. H. Evidence from high $\mathrm{Ni}$ olivines for a hybridized peridotite/pyroxenite source for orogenic andesites from the central Mexican Volcanic Belt. Geochem Geophys Geosys 9, Q03007, doi:03010.01029/02007GC001583 (2008).

161 Straub, S. M. et al. in Orogenic Andesites and Crustal Growth Vol. 385 (eds A Gomez-Tuena, S M Straub, \& G F Zellmer) 31-64, doi 10.1144/SP1385.1114 (Geological Society London Special Publication 385, 2014).

162 Morris, J. D. \& Hart, S. R. Isotopic and incompatible element constraints on the genesis of island arc volcanics from Cold Bay and Amak Island, Aleutians, and implications for mantle structure. Geochimica et Cosmochimica Acta 47, 2015-2030 (1983).

163 Ringwood, A. E. The petrological evolution of island arc systems. J Geol Soc Lond 130 (1974).

164 Gill, J. Orogenic Andesites and Plate Tectonics. (Springer, 1981).

165 Kelemen, P. B. Genesis of high Mg\# andesites and the continental crust. Contrib Mineral Petrol 120, 1-19 (1995).

166 Plank, T. \& Langmuir, C. H. An evaluation of the global variations in the major element chemistry of arc basalts. Earth Planet Sci Lett 90, 349-370 (1988).

167 Turner, S. J. \& Langmuir, C. H. The global chemical systematics of arc front stratovolcanoes: Evaluating the role of crustal processes. Earth Planet Sci Lett 422, 182-193, doi.org/110.1016/j.epsl.2015.1003.1056 (2015a).

168 Carmichael, I. S. E. The andesite aqueduct: perspectives on the evolution of intermediate magmatism in west-central $\left(105-99^{\circ} \mathrm{W}\right)$ Mexico. Contrib Mineral Petrol 143, 641-663 (2002).

169 Langmuir, C. H., Klein, E. M. \& Plank, T. in Mantle Flow and Melt Generation at Mid-Ocean Ridges Geophysical Monograph (eds J P Morgan, D K Blackman, \& J M Sinton) 183-280 (American Geophysical Union, 1992).

170 Hirose, K. Melting experiments on lherzolite KLB-1 under hydrous conditions and generation of high-magnesian andesitic melts. Geochim Cosmochim Acta 25, 42-44 (1997).

171 Wood, B. J. \& Turner, S. P. Origin of primitive high-Mg andesite: Constraints from natural examples and experiments. Earth Planet Sci Lett 283, 59-66, doi:10.1016/j.epsl.2009.1003.1032 (2009).

172 Grove, T. L. \& Till, C. B. $\mathrm{H}_{2} \mathrm{O}$-rich mantle melting near the slab-wedge interface. Contrib Mineral Petrol 174, 80, 10.1007/s00410-00019-01615-00411 (2019).

173 Gómez-Tuena, A., Langmuir, C. H., Goldstein, S. L., Straub, S. M. \& OrtegaGutierrez, F. Geochemical Evidence for Slab Melting in the Trans-Mexican Volcanic Belt. J Petrol 48, 537-562, doi:510.1093/petrology/eg11071 (2007a).

174 Defant, M. \& Drummond, M. Derivation of some modern arc magmas by melting of young subducted lithosphere. Nature 347, 662-665 (1990).

175 Kay, R. W. Aleutian Magnesian Andesites: Melts from Subducted Pacific Ocean Crust. J Volcanol Geotherm Res 4, 117-132 (1978). 
176 Yogodzinksi, G., Volynets, O. N., Koloskov, A. V., Seliverstov, N. I. \& Matvenko, V. V. Magnesian Andesites and the Subduction Component in a Strongly CalcAlkaline Series at Piip Volcano, Far Western Aleutians. J Petrol 35, Part, 163-204 (1994).

177 Kogiso, T., Hirschmann, M. \& Pertermann, M. High-pressure partial melting of mafic lithologies in the mantle. J Petrol 45, 2407-2422, doi:101093/petrology/egh101057 (2004).

178 Hauri, E. Major-element variability in the Hawaiian mantle plume. Nature 382, 415-419 (1996).

179 Gómez-Tuena, A. et al. The origin of a primitive trondhjemite from the TransMexican Volcanic Belt and its implications for the construction of a modern continental arc. Geochim Cosmochim Acta 36, 471-474, doi: 410.1130/G24687A (2008).

180 Bindeman, I. N., Ponomareva, V. V., Bailey, J. C. \& Valley, J. W. Volcanic arc of Kamchatka: a province with high-18O magma sources and large-scale 18O/16O depletion of the upper crust. Geochimica Cosmochimica Acta 68, 841-865, doi:810.1016/j.gca.2003.1007.1009 (2004).

181 Bryant, J. A., Yogodzinksi, G. M. \& Churikova, T. G. High-Mg\# andesitic lavas of the Shisheisky Complex, Northern Kamchatka: implications for primitive calcalkaline magmatism. Contrib Mineral Petrol 161, 791-810, doi 710.1007/s0041000010-00565-00414 (2011).

182 Portnyagin, M., Bindeman, I. N., Hoernle, K. \& Hauff, F. in Volcanism and Subduction: The Kamchatka Region Vol. 172 Geophysical Monograph Series (eds J Eichelberger et al.) 199-239 (American Geophysical Union, 2007).

183 Price, R. C. et al. The Anatomy of an AndesiteVolcano: a Time-Stratigraphic Study of Andesite Petrogenesis and Crustal Evolution at Ruapehu Volcano, New Zealand. J Petrol 53, 2139-2189, doi:2110.1093/petrology/egs2050 (2012).

184 Cameron, E. et al. The petrology, geochronology and geochemistry of Hauhungatahi volcano, S.W. Taupo Volcanic Zone. J Volcanol Geotherm Res 190, 179-191, doi:110.1016/j.jvolgeores.2009.1007.1002 (2010).

185 Beier, C., Haase, K. M., Brandl, P. A. \& Krumm, S. H. Primitive andesites from the Taupo Volcanic Zone formed by magma mixing. Contrib Mineral Petrol 173, 33, doi 10.1007/s00410-00017-01354-00410 (2017).

186 Yogodzinski, G. M., Kay, R. W., Volynets, O. N., Koloskov, A. V. \& Kay, S. M. Magnesian andesite in the western Aleutian Komandorsly region: Implications for slab melting and processes in the mantle wedge. Geol Soc Am Bull 107, 505-519 (1995).

187 Borg, L. E., Clynne, M. A. \& Bullen, T. D. The variable role of slab-derived fluids in the generation of a suite of primitive calc-alkaline lavas from the southernmost Cascades, California. Can Mineral 35, 425-452 (1997).

188 Bullen, T. D. \& Clynne, M. A. Trace element and isotopic constraints on magmatic evolution at Lassen Volcanic center. J Geophys Res 95, 19671-19691 (1990).

189 Sisson, T. W., Salters, V. J. M. \& Larson, P. B. Petrogenesis of Mount Rainier andesite: Magma flux and geologic controls on the contrasting differentiation styles at stratovolcanoes of the southern Washington Cascades. Geol Soc Am Bull 126, 122-144, doi: 110.1130/B30852.30851 (2014). 
190 Grove, T. L., Parman, S. W., Bowring, S. A., Price, R. C. \& Baker, M. B. The role of an $\mathrm{H} 2 \mathrm{O}$-rich fluid component in the generation of primitive basaltic andesites and andesites from Mt. Shasta, N California. Contrib Mineral Petrol 142, 375-396 (2002).

191 Hacker, B. R., Kelemen, P. B. \& Behn, M. D. Differentiation of the continental crust by relamination. Earth Planet Sci Lett 307 501-516, doi:510.1016/j.epsl.2011.1005.1024 (2011).

192 Eichelberger, J. C. Andesitic volcanism and crustal evolution. Nature 275, 21-27 (1978).

193 Reubi, O. \& Blundy, J. Assimilation of Plutonic Root:, Formation of High-K 'Exotic' Melt Inclusions and Genesis of Andesitic Magmas at Volcan De Colima, Mexico. J Petrol 49, 2221-2243,doi:2210.1093/petrology/egn2066 (2009).

194 Streck, M. J., Leeman, W. P. \& Chesley, J. High-magnesian andesite from Mount Shasta: a product of magma mixing and contamination, not a primitive mantle melt. Geochim Cosmochim Acta 35, 351-354, doi:310.1130/G23286A.23281 (2007).

195 Kent, A. J. R., Darr, C., Koleszar, A. M., Salisbury, M. J. \& Cooper, K. M. Preferential eruption of andesitic magmas through recharge filtering. Nature Geoscience 3, 631-636; doi: 610.1038/ngeo1924 (2010).

196 Nixon, G. T. Petrology of the younger andesites and dacites of Iztaccihuatl Volcano, Mexico: II. Chemical stratigraphy, magma mixing, and the composition of basaltic magma influx. J Petrol 29, 265-303 (1988b).

197 Straub, S. M. \& Martin-Del Pozzo, A. L. The significance of phenocryst diversity in tephra from recent eruptions at Popocatepetl volcano (Central Mexico). Contrib Mineral Petrol 140, 487-510 (2001).

198 Streck, M. J. \& Leeman, W. P. Petrology of "Mt. Shasta" high-magnesian andesite (HMA): A product of multi-stage crustal assembly. Am Min 102, 216-240, doi.org/210.2138/am-2018-6151 (2018).

199 Leeman, W. P. \& Smith, D. J. The role of magma mixing, identification of mafic magma inputs, and structure of the underlying magmatic system at Mount St. Helens. American Mineralogist 103, 1925-1944 (2018).

200 Mamani, M., Tassara, A. \& Woerner, G. Composition and structural control of crustal domains in the central Andes. Geochem Geophys Geosys 8, doi:10.1029/2007GC001925 (2008).

201 Farner, M. J. \& Lee, C. A. Effects of crustal thickness on magmatic differentiation in subduction zone volcanism: A global study. Earth Planet Sci Lett 470, 96-107, dx.doi.org/110.1016/j.epsl.2017.1004.1025 (2017).

202 Bindeman, I. N. \& Bailey, T. R. Trace elements in anorthite megacrysts from the Kurile Island Arc: a window to across-arc geochemical variations in magma compositions. Earth Planet Sci Lett 169, 209-226 (1999).

203 Sas, M., Debari, S. M., Clynne, M. A. \& Rusk, B. G. Using mineral geochemistry to decipher slab, mantle, and crustal input in the generation of high-Mg andesites and basaltic andesites from the northern Cascade Arc. American Mineralogist 102, 948-965, doi:10.2138/am-2017-5756 (2017).

204 Zamboni, D. et al. New insights into the Aeolian Islands and other arc source compositions from high-precision olivine chemistry. Lithos 272-273, 185-191, dx.doi.org/110.1016/j.lithos.2016.1012.1004 (2017). 
Kent, A. J. R. \& Elliott, T. R. Melt inclusions in the Mariana arc lavas: implications for the formation and evolution of arc magmas. Chem Geol 183, 265-288 (2002).

206 Rowe, M. C., Nielsen, R. L. \& Kent, A. J. K. Anomalously high Fe contents in rehomogenized olivine-hosted melt inclusions from oxidized magmas. American Mineralogist 91, 82-91, doi: 10.2138/am.2006.1818 (2006).

207 Straub, S. M. et al. The processes of melt differentiation in arc volcanic rocks: Insights from OIB-type arc magmas in the central Mexican Volcanic Belt. J Petrol 54 665-701, doi:610.1093/petrology/egs1081 (2013a).

208 McGee, L. E., Beier, C., Smith, I. E. M. \& Turner, S. P. Dynamics of melting beneath a small-scale basaltic system: a U-Th-Ra study from Rangitoto volcano, Auckland volcanic field, New Zealand. Contrib Mineral Petrol 162, 547-563, doi 510.1007/s00410-00011-00611-x (2011).

209 Larrea, P., Widom, E., Siebe, C., Salinas, S. \& Kuentz, D. A re-interpretation of the petrogenesis of Paricutin volcano: distinguishing crustal contamination from mantle heterogeneity. Chem Geol 504, 66-82, doi.org/10.1016/j.chemgeo.2018.1010.1026 (2019).

210 Workman, R. K. \& Hart, S. R. Major and Trace Element Composition of the Depleted MORB mantle (DMM). Earth Planet Sci Lett 231, 53- 72 (2005).

211 McKenzie, D. \& O'Nions, R. K. The source regions of ocean island basalts. J Pet 36, 133-159 (1995).

212 Marini, J. C., Chauvel, C. \& Maury, R. C. Hf isotope compositions of northern Luzon arc lavas suggest involvement of pelagic sediments in their source. Contrib Mineral Petrol 149, 216-232 (2005).

213 Klaver, K. et al. Temporal and spatial variations in provenance of Eastern Mediterranean Sea sediments: Implications for Aegean and Aeolian arc volcanism. Geochimica Cosmochimica Acta 153 149-168, dx.doi.org/110.1016/j.gca.2015.1001.1007 (2015).

214 Rudnick, R. \& Gao, S. in The Crust Vol. 3 Treatise on Geochemistry (ed R.L. Rudnick) 1-64 (Elsevier-Pergamon, 2002).

215 Gale, A., Dalton, C. A., Langmuir, C. H., Su, Y. \& Schilling, J. G. The mean composition of ocean ridge basalts. Geochem Geophys Geosys 14, doi:10.1029/2012GC004334 (2013).

216 Salters, V. J. M., Mallick, S., Hart, S. R., Langmuir, C. H. \& Stracke, A. Domains of depleted mantle: New evidence from hafnium and neodymium isotopes. Geochem Geophys Geosys 12, doi:10.1029/2011GC003617 (2011).

217 Shimaoka, A., Imamura, M. \& Kaneoka, I. Beryllium isotopic systematics in island arc volcanic rocks from northeast Japan: Implications for the incorporation of oceanic sediments into island arc magmas. Chem Geol 443, 158-172, dx.doi.org/110.1016/j.chemgeo.2016.1008.1032 (2016).

218 Tera, F., Brown, L., Morris, J. \& Sacks, I. S. Sediment incorporation in island-arc magmas: Inferences from ${ }^{10}$ Be. Geochim Cosmochim Acta 50, 535-550 (1986).

219 Freymuth, H., Andersen, M. B. \& Elliott, T. Uranium isotope fractionation during slab dehydration beneath the Izu arc. Earth Planet Sci Lett 522, 244-225, doi.org/210.1016/j.epsl.2019.1007.1006 (2019).

220 Nielsen, S. G. et al. Tracking along-arc sediment inputs to the Aleutian arc using thallium isotopes. Geochimica Cosmochimica Acta 181, 217-237, 
http://dx.doi.org/210.1016/j.gca.2016.1003.1010 (2016).

1312221 Bellot, N. et al. Ce isotope systematics of island arc lavas from the Lesser Antilles.

1313

1314

1315

1316

1317

1318

1319

1320

1321

1322

1323

1324

1325

1326

1327

1328

1329

1330

1331

1332

1333

1334

1335

1336

1337

1338

1339

1340

1341

1342

1343

1344

1345

1346

1347

1348

Geochimica Cosmochimica Acta 168, 261-279, dx.doi.org/210.1016/j.gca.2015.1007.1002 (2015).

222 Luhr, J. F., Pier, J. G., Aranda-Gomez, J. J. \& Posedek, F. A. Crustal contamination in early Basin-and-Range hawaiites of the Los Encinos Volcanic Field, central Mexico. Contrib Mineral Petrol 118, 321-339 (1995a).

223 Luhr, J. F., Aranda-Gomez, J. J. \& Housh, T. San Quintin Volcanic Field, Baja California Norte, Mexico: Geology, petrology, and geochemistry. J Geophys Res 100, 10353-10380 (1995b).

224 Cai, Y. et al. Hafnium isotope evidence for slab melt contributions in hot slab arcs: an example of the Central Mexican Volcanic Belt. Chem Geol 377, 45-55, http://dx.doi.org/10.1016/j.chemgeo.2014.1004.1002 (2014).

225 Guilbaud, M.-N. et al. Petrographic, geochemical, and isotopic (Sr-Nd-Pb-Os) study of Plio-Quaternary volcanics and the Tertiary basement in the JorulloTacámbaro area, Michoacán-Guanajuato Volcanic Field, Mexico. Journal of Petrology, doi:10.1093/petrology/egaa006 (2020).

226 Risse, A., Trumbull, R. B., Kay, S. M., Coira, B. \& Romer, R. L. Multi-stage Evolution of Late Neogene Mantle-derived Magmas from the Central Andes Back-arc in the Southern Puna Plateau of Argentina. J Petrol 10, 1963-1995, doi:1910.1093/petrology/egt1038 (2013).

227 Søager, N., Holm, P. M. \& Llambías, E. J. Payenia volcanic province, southern Mendoza, Argentina: OIB mantle upwelling in a backarc environment. Chem Geol 349-350, 36-53, dx.doi.org/10.1016/j.chemgeo.2013.1004.1007 (2013).

228 Søager, N., Holm, P. M. \& Thirlwall, M. F. Sr, Nd, Pb and Hf isotopic constraints on mantle sources and crustal contaminants in the Payenia volcanic province, Argentina. Lithos 212-215, 368-378, dx.doi.org/310.1016/j.lithos.2014.1011.1026 (2015).

229 GeoROC. Geochemistry of Rocks of the Oceans and Continents. http://georoc.mpch-mainz.gwdg.de/georoc/ (2019).

230 Carr, M. J., Feigenson, M. D., Bolge, L. L., Walker, J. A. \& Gazel, E. doi:10.1594/IEDA/100403 (2013).

231 Mamani, M., Wörner, G. \& Sempere, T. Geochemical variations in igneous rocks of the Central Andean orocline $\left(13^{\circ} \mathrm{S}\right.$ to $\left.18^{\circ} \mathrm{S}\right)$ : Tracing crustal thickening and magma generation through time and space Bull Geol Soc Am 122, 162 - 182 doi:doi: 10.1130/B26538.1 (2010).

232 Vermeesch, P. IsoplotR: A free and open toolbox for geochronology. Geosciences Frontiers 9, 1479-1493, doi.org/1410.1016/j.gsf.2018.1404.1001 (2019). 


\section{ACKNOWLEDGEMENTS}

1352

1353

1354

1355

SMS acknowledges support from National Science Foundation grants OCE 09-61359, EAR 12-20481, EAR 19-21624 and a Kyoto University Visiting Fellowship. AGT studies were supported by Consejo Nacional de Ciencia y Tecnología (CONACyT, Mexico) grant 239494.

\section{AUTHOR CONTRIBUTIONS}

SMS perceived and drafted the manuscript, which was revised and amended by PV and AGT. PV provided updated the rates of forearc erosion and sediment subduction (Supplementary Information). All authors contributed to the discussion.

\section{COMPETING INTERESTS}

The authors declare no competing interests.

\section{Peer review information}

Nature Reviews Earth \& Environment thanks A. Stracke, C. Stern, S. Kay and the other anonymous reviewer(s) for their contribution to the peer review of this work

\section{Publisher's note}

Springer Nature remains neutral with regard to jurisdictional claims in published maps and institutional affiliations.

\section{Supplementary information:}

Supplementary information is available for this paper at https://doi.org/10.1038/s415XXXXX-XXXX-X

\section{KEY POINTS}

- Subduction zones recycle upper plate crust by subduction erosion in volumes that can exceed those of the subducted trench sediments.

- The composition of the eroded crust is varied and can include upper and lower continental crust as well as oceanic crust.

- Strong compositional forearc-arc links exist.

- Arc magma petrogenesis plays a key role in elucidating forearc-arc connectivity. 
- Tectonically eroded crust can refertilize shallow and deep mantle alike.

1380

1381 
1383 Figure 1: Subduction zone cartoon of erosive margin. The location of the frontal prism, resistive 1384 backstop and the subduction channel are shown in the right-hand inset. AOC - altered oceanic

1385

1386

1387 1388 crust. Material from the frontal prism can be eroded by incorporation into the subduction channel. Adapted with permission from refs. $2,5,6$.

Figure 2: Classification of margins as erosive or accretionary and comparison to arc $\varepsilon N d$ values. Data represents the average $\varepsilon \mathrm{Nd}$ values for $\mathrm{n}=785$ Quaternary arc volcanoes, calculated from available GeoROC data ${ }^{229}$ and pre-compiled data sets of the Central American Volcanic Arc ${ }^{230}$ and of the Central Andean Volcanic Zone ${ }^{231}$.

Figure 3: Geochemical variations of global arcs with details from the Transmexican Volcanic Belt (TMVB). a: $\varepsilon N d$ vs $\varepsilon H f$ of the TMVB $(n=598)^{229}$, global arc data (grey, $\left.n=4742\right)^{229}$, the Mexican forearc crust ${ }^{5,6}$ and average trench sediment (brown diamond) ${ }^{157}$. b: ${ }^{3} \mathrm{He} /{ }^{4} \mathrm{He}$ (Ra) vs. $\delta^{18} \mathrm{O}(\%$ o) of olivine phenocrysts from a subgroup of TMVB basalts and andesites. Combined high, mantle-like ${ }^{3} \mathrm{He} /{ }^{4} \mathrm{He}(\sim 7-8 \mathrm{Ra})$ and high crustal $\delta^{18} \mathrm{O}(>5 \%$ ) indicates that the melt originated from a mantle infiltrated by crustal slab components ${ }^{6}$. c: Mixing systematics in $\varepsilon N d$ vs $\varepsilon H f$ space. Curved (A) vs straight (B) trends resulting from mixing of end member with similar $\varepsilon \mathrm{Nd}$ and $\varepsilon \mathrm{Hf}$, but different $\mathrm{Nd} / \mathrm{Hf}$ ratios. $\mathrm{M}$ - mantle, $\mathrm{S}$ - trench sediment, $\mathrm{C}$ - crust with low $\mathrm{Nd} / \mathrm{Hf}$ (such as continental crust or unradiogenic intraplate crust). Modified and updated after ref. ${ }^{6}$.

Figure 4: Arc and forearc compositional variations in the Western Transmexican Volcanic Belt. Data is presented from andesite volcanoes Sangangüey, Tequila and Colima and forearc lithologies (river mouths sediments and bedrock). Forearc lithologies include the Late Cretaceous Puerto Vallarta Batholith (PVB, 82 Ma) and coeval rhyolites (R), the Manzanillo Batholith (MS, $\sim 73 \mathrm{Ma}$ ), and the Paleocene Jilotlán Batholith (JP $\sim 58 \mathrm{Ma}$ ), which intrude early Cretaceous rocks and associated volcano-sedimentary sequences (VS), and Paleocene felsic plutonic rocks (FP). Colored stippled lines represent the trajectories followed by subducted material. EPR-East Pacific Rise. Modified and updated from ref. ${ }^{5}$.

Figure 5: U-Pb dating of Malinche zircons. a: $\mathrm{U}-\mathrm{Pb}$ concordia diagram of Malinche zircons compared to detrital zircons from the Papagayo river and a Pliocene-Quaternary, $182 \mathrm{~m}$ thick hemipelagic gray mud unit of 0-5 Ma drilled at DSDP Site 487 (near the trench). Data-point error ellipses at the $2 \sigma$ level. Constructed with IsoplotR 232 . $\underline{\text { : }}$ Cathodoluminescence images of Malinche's zircon xenocrysts with ${ }^{238} \mathrm{U} / 206 \mathrm{~Pb}$ ages in Ma. Inherited cores of Proterozoic and Paleozoic age (red) are overgrown by effectively zero age (<2 Ma) rims (green), which grew in Quaternary Malinche magmas. Modified from ref.7.

Figure 6: Major element versus isotopic systematics of global arc magmas. $\underline{\text { a: }} \mathrm{SiO}_{2} \mathrm{wt} \%$ vs ${ }^{207} \mathrm{~Pb} / 204 \mathrm{~Pb}$ for global arc volcanic rocks ( $\mathrm{n}=3683$ ). A subset of six arcs is highlighted: Mexico, Central America (Costa Rica, Nicaragua, and El Salvador), Andean Southern Volcanic Zone (SVZ), Sunda, Banda and the Southern Antilles. Horizontal lines represent the average ${ }^{207} \mathrm{~Pb} / 204 \mathrm{~Pb}$ of an arc. b: Histogram of correlation coefficients for $\mathrm{SiO}_{2}$ vs. ${ }^{207} \mathrm{~Pb} /{ }^{204} \mathrm{~Pb}$ from 38 arc segments ${ }^{229}$. All arc data are from ref. ${ }^{229}$.

Figure 7: Isotopic systematics of global arc magmas. a: $\varepsilon N d v s \varepsilon H f$ of global arc volcanic rocks of 
1422 Quaternary age ( $\mathrm{n}=1054)$ compared to MORB ${ }^{215}$, oceanic intraplate basalts ${ }^{216}$ and global trench 1423 sediments ${ }^{110}$. b: $\varepsilon N d$ vs $\varepsilon H f$ of global arcs with six arcs highlighted: Mexico, Central America 1424 (Costa Rica, Nicaragua, and El Salvador), Andean Southern Volcanic Zone (SVZ), Sunda, Banda 1425 and the Southern Antilles. $\varepsilon \mathrm{Hf}$ is available for only $22 \%$ of the samples for which $\varepsilon \mathrm{Nd}$ data is 1426 available. Notably, $\varepsilon H f$ is missing for some samples that have the lowest $\varepsilon N d$ values (-1.7 to -10.6) 1427 of any magmas from the Andean Central Volcanic Zone (CVZ). Red stippled lines indicate 1428 typical 'curved' mantle-sediment mixing trends. All arc data are from ref. ${ }^{229}$.

1429 
1430 GLOSSARY TERMS

1431 Subduction erosion [tectonic removal of upper plate material in subduction zones]

1432 Frontal erosion [tectonic removal of material from the frontal part of the forearc]

1433 Basal erosion [tectonic removal of upper plate material from the underside of the

$1434 \quad$ upper plate]

1435 Forearc [region between arc and trench]

1436 Frontal prism [an actively deforming wedge at the toe of the forearc]

1437 Backstop [Point of coherent, resistive upper plate rock framework closest to the

1438 trench]

1439 Accretionary prism [wedge-shaped body constructed mostly of sediment that has been

$1440 \quad$ scraped off the subducting plate]

1441 Frontal accretion [accretion of lower plate material to the forearc]

1442 Subduction channel [Plate boundary shear zone conveying material from the shallow part

1443 of the subduction zone toward the mantle].

1444 Underplating [accretion of lower plate material to the base of the upper plate]

1445 Hydrofracturing [rock failure induced by overpressured fluids]

1447 Slab fluids [fluid expelled from subducting lithospheric plate into the mantle wedge]

1448 Slab partial melts [partial melt released from subducted lithologies into the mantle wedge]

1449 Slab diapirs [low density material that buoyantly rises from the slab into the mantle 1450 wedge]

1451 Mélange diapirs [slab diapirs rising from zones of the intensely sheared and mixed 1452 metamorphic sedimentary and igneous rocks at the interface between the 1453 subducted slab and the mantle] 
1454 Primary arc magmas [mantle wedge magmas prior to modification in the crustal basement].

1455 Arc crust production rate [rate of arc crustal growth by addition of mantle-derived melts to

1456

1457

$1458 \varepsilon \mathrm{Nd}$

1459

$1460 \quad \varepsilon \mathrm{Hf}$

1461

1462

1463 Corner flow

1464

1465

1466

1467

1468

1469

1470

1471

1472

1473

1474

1475

1476

1477 arc crust per time increment, given in $\mathrm{km}^{3} / \mathrm{per} \mathrm{km}$ of arc length/my, or $\mathrm{km}^{3} / \mathrm{my}$, when normalized to length of global arcs].

[deviation of ${ }^{144} \mathrm{Nd} /{ }^{143} \mathrm{Nd}$ from the Chondritic Uniform Reservoir (CHUR) ratio; calculated as $\left.\left.\varepsilon N d=\left({ }^{144} \mathrm{Nd} /{ }^{143} \mathrm{Nd} / 0.51263\right)-1\right]^{*} 10000\right]$.

[deviation of ${ }^{176} \mathrm{Hf} / 177 \mathrm{H}$ from the Chondritic Uniform Reservoir (CHUR) ratio; calculated as $\left.\left.\varepsilon H f:\left({ }^{176} \mathrm{Hf} / 177 \mathrm{Hf} / 0.282785\right)-1\right]^{*} 10000\right]$.

Recharge mixing mixing of different magma batches incited by the ascent of new primary melt. mantle wedge flow towards the subducting slab induced by viscous coupling between the downgoing slab and overlying mantle wedge.

mantle wedge that is not affected by a slab component.

the molar ratio of $\mathrm{Mg} /\left(\mathrm{Mg}^{+} \mathrm{Fe}^{2+}\right)$ in magmas. Primary mantle melts usually have a $M g \# \geq 72$. 
1478 TOC summary

1479 Subduction erosion transports crustal material from the upper plate at subduction zones

1480 into the mantle and thus likely contributes to the composition of arc magmas. This

1481 Review discusses the evidence for subduction erosion globally and outlines how a

1482 contribution of tectonically eroded crust can be identified in arc magmas.

1483

1484

1485 